\title{
Review
}

Journal of Innate

Immunity
J Innate Immun 2016;8:330-349

DOI: $10.1159 / 000444256$
Received: November 11, 2015

Accepted after revision: January 25, 2016 Published online: March 18, 2016

\section{Modulating Innate and Adaptive Immunity by (R)-Roscovitine: Potential Therapeutic Opportunity in Cystic Fibrosis}

\author{
Laurent Meijer $^{\mathrm{a}}$ Deborah J. Nelson ${ }^{\mathrm{b}}$ Vladimir Riazanski ${ }^{\mathrm{b}}$
}

Aida G. Gabdoulkhakova ${ }^{b}$ Geneviève Hery-Arnaud ${ }^{c, d}$ Rozenn Le Berre ${ }^{d, e}$

Nadège Loaëc ${ }^{a}$ Nassima Oumata ${ }^{a}$ Hervé Galons $^{f}$ Emmanuel Nowak $^{g}$

Laetitia Gueganton $^{\text {h }}$ Guillaume Dorothée ${ }^{i, j}$ Michaela Prochazkova ${ }^{k}$

Bradford Hall $^{k}$ Ashok B. Kulkarni ${ }^{k}$ Robert D. Gray' Adriano G. Rossi ${ }^{\prime}$

Véronique Witko-Sarsat ${ }^{m} \quad$ Caroline Norez $^{\mathrm{n}} \quad$ Frédéric Becq $^{\mathrm{n}} \quad$ Denis Ravel $^{\circ}$

Dominique Mottierg Gilles Rault ${ }^{\text {h }}$

${ }^{a}$ Centre de Perharidy, ManRos Therapeutics, Roscoff, France; ${ }^{b}$ Department of Pharmacological and Physiological Sciences, The University of Chicago, Chicago, III., USA; ' Unité de Bactériologie, Hôpital de la Cavale Blanche, CHRU Brest, ${ }^{d}$ EA3882-LUBEM, Université de Brest, UFR de Médecine et des Sciences de la Santé, and 'Département de Médecine Interne et Pneumologie, CHRU Brest, Brest, ${ }^{\mathrm{f}}$ Unité de Technologies Chimiques et Biologiques pour la Santé, Université Paris Descartes UMR-S 1022 INSERM, Paris, ${ }^{9}$ Hôpital de la Cavale Blanche, CHRU Brest, Centre d'Investigation Clinique, INSERM CIC 1412, Brest, h'Fondation Ildys, Roscoff, 'Immune System, Neuroinflammation and Neurodegenerative Diseases Laboratory, Inflammation-Immunopathology-Biotherapy Department (DHU i2B), CdR Saint-Antoine, INSERM, UMRS 938, and ${ }^{\mathrm{j} H o ̂ p}$ ital Saint-Antoine, CdR Saint-Antoine, UMRS 938, UPMC University Paris 06, Sorbonne Universités, Paris, France; ${ }^{\mathrm{K}}$ Functional Genomics Section, Laboratory of Cell and Developmental Biology, National Institute of Dental and Craniofacial Research, NIH, Bethesda, Md., USA; 'MRC Centre for Inflammation Research, Queen's Medical Research Institute, University of Edinburgh Medical School, Edinburgh, UK; mInstitut Cochin,

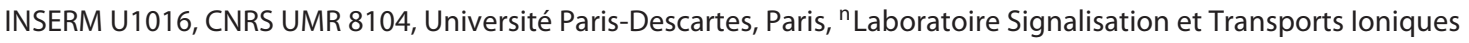
Membranaires, CNRS, Université de Poitiers, Poitiers, and ${ }^{\circ}$ Initial R\&D Consulting, Paris, France

\section{Key Words}

CFTR · Corrector · Cystic fibrosis · Infection · Inflammation · Innate immunity $\cdot$ Pseudomonas aeruginosa $\cdot$ Roscovitine . Seliciclib · TRPC6

\section{Abstract \\ (R)-Roscovitine, a pharmacological inhibitor of kinases, is currently in phase II clinical trial as a drug candidate for the treatment of cancers, Cushing's disease and rheumatoid ar-}

thritis. We here review the data that support the investigation of (R)-roscovitine as a potential therapeutic agent for the treatment of cystic fibrosis (CF). (R)-Roscovitine displays four independent properties that may favorably combine against CF: (1) it partially protects F508del-CFTR from proteolytic degradation and favors its trafficking to the plasma membrane; (2) by increasing membrane targeting of the TRPC6 ion channel, it rescues acidification in phagolysosomes of CF alveolar macrophages (which show abnormally high $\mathrm{pH}$ ) and consequently restores their bactericidal activ-

\section{KARGER}

E-Mail karger@karger.com

www.karger.com/jin
(C) 2016 S. Karger AG, Basel

$1662-811 \mathrm{X} / 16 / 0084-0330 \$ 39.50 / 0$
Dr. Laurent Meijer

ManRos Therapeutics

Centre de Perharidy

FR-29680 Roscoff (France)

E-Mail meijer@manros-therapeutics.com 
ity; (3) its effects on neutrophils (induction of apoptosis), eosinophils (inhibition of degranulation/induction of apoptosis) and lymphocytes (modification of the Th17/Treg balance in favor of the differentiation of anti-inflammatory lymphocytes and reduced production of various interleukins, notably IL-17A) contribute to the resolution of inflammation and restoration of innate immunity, and (4) roscovitine displays analgesic properties in animal pain models. The fact that (R)roscovitine has undergone extensive preclinical safety/pharmacology studies, and phase I and II clinical trials in cancer patients, encourages its repurposing as a CF drug candidate.

(c) 2016 S. Karger AG, Basel

\section{Introduction}

Cystic fibrosis (CF) is a genetic disease affecting the gene encoding the cystic fibrosis transmembrane conductance regulator (CFTR) ion channel (7q31.2, 1,480 amino acids, $168 \mathrm{kDa}$ ), allowing the passage of chloride and bicarbonate ions across the apical membrane of epithelial cells. The CFTR channel displays five domains: two hydrophobic membrane-spanning domains (each constituted of six transmembrane helical segments), two hydrophilic nucleotide-binding domains (NBD) and a cytoplasmic regulatory domain which is encoded by exon 13 and contains numerous charged residues and most of the potential phosphorylation sites. The most frequent mutation site (F508del) is localized in NBD1. Loss of function of CFTR translates into pulmonary problems, including dehydration and overproduction of mucus, respiratory difficulties, chronic infection (Pseudomonas aeruginosa in particular) and inflammation. Good overviews on various aspects of $\mathrm{CF}$ can be found in several recent reviews [1-6].

Lung damage secondary to chronic infection is the main cause of death in CF patients. Treatment of lung disease to reduce the impact of dysregulated innate immunity, infections, inflammation and subsequent lung injury is, therefore, of major importance [7-13]. Improved survival and increased mean age of CF patients worldwide is encouraging [14], but pulmonary infections remain the main problem for CF patients, as mortality in CF directly relates to compromised respiratory function. Despite some progress in the treatment of CF in recent years, transplantation remains the only therapeutic option for subjects reaching the terminal phase of pulmonary disease. Currently, conventional medical treatment has little to offer to these late-stage CF patients and effective new agents need to be identified. The current devel-

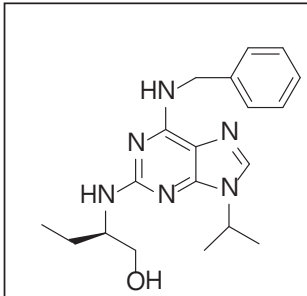

(R)-roscovitine

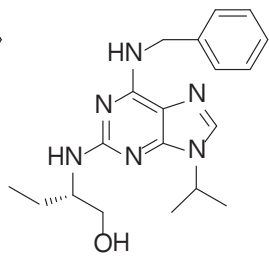

(S)-roscovitine

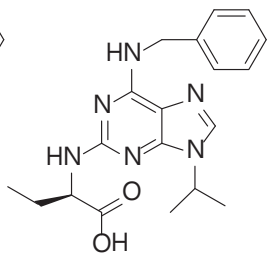

Metabolite M3
Fig. 1. Structure of the two isomers of roscovitine and M3, the major metabolite of $(\mathrm{R})$-roscovitine. Isomer $\mathrm{R}$ of roscovitine has been developed as a cancer drug candidate under the name seliciclib (CYC202).

opment of new drugs with antimicrobial or anti-inflammatory properties, and the recent discovery and use of CFTR correctors and potentiators provide increasing hope for the treatment of CF [15-23].

We here review recent evidence showing that roscovitine, a protein kinase inhibitor developed as a clinical phase II anticancer drug, rescues the trafficking defect of the F508del-CFTR protein, positively affects various aspects of the biology of innate immune cells, leading to potentiation of the antimicrobial defense and down-regulation of the inflammatory process, and displays analgesic properties. This body of results advocates in favor of the evaluation of roscovitine for the treatment of CF.

\section{Roscovitine: A Wide-Potential Kinase Inhibitor}

The 2,6,9-trisubstituted purine (R)-roscovitine (referred to as roscovitine above and in the rest of the article; fig. 1) was discovered in 1997 as a pharmacological inhibitor of cyclin-dependent kinases (CDKs) [24, 25; reviews: 26-29], a class of regulators essential for cell division and other major cellular functions [reviews: 29-31]. Its selectivity has been extensively studied: it interacts with various $C D K s$, casein kinases (CK1), dual specificity tyrosine phosphorylation-regulated kinases (DYRKs) as well as with pyridoxal kinase [32-34]. Roscovitine was cocrystallized with CDK2, CDK5, CDK9 and pyridoxal kinase $[24,33,35,36]$.

Roscovitine has been patented (its synthesis and some derivatives) in the USA, Europe and Japan for several applications [37]. The 'Centre National de la Recherche Scientifique' (CNRS) holds exclusive rights to the patent that applies to cancers, infections and inflammatory dis- 
eases as granted to Cyclacel Pharmaceuticals. A second patent covers the use of roscovitine for the treatment of cerebrovascular conditions (e.g. stroke) and was licensed by the CNRS to Neurokin [38]. Finally, a third patent proposing the use of roscovitine for the treatment of CF was purchased from the CNRS and the University of Poitiers by ManRos Therapeutics [39]. The synthesis of roscovitine and related analogues has been largely described and optimized [40].

The therapeutic potential of roscovitine has been evaluated for numerous medical and veterinary indications. In addition to cancer, we can cite stroke [41], Parkinson's disease [42], Alzheimer's disease [L.H. Tsai, pers. commun.], cranial trauma [43], pain signaling (see 'Roscovitine Has Analgesic Properties', below), various viral infections [44], polycystic kidney disease [45, 46], glomerulonephritis [47-50], glaucoma [51, 52], Lambert-Eaton syndrome [53-55], deafness [56], Timothy syndrome [57-59], fibrosis [60], Cushing's disease [61, 62] and diabetes [63]. These studies have made it to preclinical trials, with the exception of glaucoma, glomerulonephritis and Cushing's disease, where roscovitine entered clinical trials. In cancer research, Cyclacel Pharmaceuticals has conducted preclinical, clinical phase I [64-67] and clinical phase II [68] trials with roscovitine under the name seliciclib or CYC202. Non-small cell lung cancer, breast cancer and nasopharyngeal cancer have been the main indications [68]. Recently, roscovitine has entered clinical trials for the treatment of Cushing's disease $[61,62,69]$ and rheumatoid arthritis [70]. In the animal breeding field, roscovitine has been used as a tool to synchronize nucleus donor cells for the cloning of numerous mammals [71, 72].

Kinetic biodistribution analysis in rats revealed that the highest area under the curve for roscovitine was observed in the lungs [73]. Several mouse models of lung inflammation or injury were efficiently treated with roscovitine by intraperitoneal administration: bleomycin-induced lung injury [74], lipoteichoic acid-and Streptococcus pneumoniae-induced lung inflammation [75], and lung injury induced by mechanical ventilation [76]. Furthermore, roscovitine has been evaluated in phase IIa clinical trials against non-small cell lung cancer, where a substantial increase in overall survival was observed (388 vs. 218 days in the placebo arm) despite no difference in progression-free survival [68]. Altogether, these data demonstrate that the lung is a viable target for roscovitine.

Roscovitine is orally bioavailable in man [66-68] and rodents $[73,77]$. Once in the organism, roscovitine is rap- idly metabolized by the liver, essentially by oxidation [27]. The main metabolite is the carboxylate product (M3; fig. 1) [66, 67, 73, 77], which does not inhibit the kinases targeted by roscovitine but may account for other effects of the drug [77-79]. Although the half-life of M3 in humans is similar to that of roscovitine $[66,67]$, its CFfavorable biological activity could extend that of roscovitine in CF treatment. Alternatively, the M3 compound could feasibly be developed as a drug candidate per se. Indeed, since it is essentially 'kinase dead', the toxic effects of roscovitine associated with its antiproliferative effects should thus be considerably reduced, permitting chronic administration of M3 over long periods and/or an increase in the treatment dose. As inhibition of CDKs appears to be important regarding the effects exerted by roscovitine on neutrophils, this could limit the antiinflammatory action of $\mathrm{M} 3$ on $\mathrm{CF}$, thus normalizing the inflammatory response in CF rather than completely abrogating it. It seems, therefore, possible to envisage the development of M3, or one of its analogues, as an alternative CF drug candidate derived from roscovitine.

\section{Roscovitine and CF}

Roscovitine Protects the Chloride Channel F508del-

CFTR from Proteolytic Degradation and Acts as a

Corrector for Its Membrane Localization

The described CFTR mutations are grouped into class I (mutations leading to lack of CFTR protein synthesis), class II (mutations leading to anomalies in CFTR processing, such as disruption of folding and trafficking to the surface), class III (mutations leading to defective regulation or gating of CFTR), class IV (mutations leading to defective chloride conductance) and class V (mutations leading to alternative splicing and production of insufficient quantity of CFTR polypeptide) [17, 18]. Alterations in CFTR activity in CF, thus, originate from different causes, depending on the type of mutation. Although 2002 mutations have been described in CFTR (http:// www.genet.sickkids.on.ca/StatisticsPage.html), deletion of the codon corresponding to phenylalanine 508 (F508del-CFTR) is by far the most frequent, representing almost $70 \%$ of all CF cases. Only five other mutations (G542X, G551D, W1282X, N1303K and R553X) represent more than $1 \%$ of all CF cases. All other mutations are rare and even exceptional, often uniquely detected in a single family.

The F508del-CFTR protein is expressed normally but, due to misfolding, it is not transported to the apical mem- 
Fig. 2. Roscovitine corrects the trafficking defect of F508del-CFTR by regulating its proteolytic degradation. Abnormally folded F508del-CFTR is taken up by the ER quality control (ERQC) system. It binds to the calnexin chaperone in a calcium-dependent manner. The complex is then taken up by the ER-associated degradation (ERAD) pathway for proteolytic degradation by the proteasome. Roscovitine depletes $\mathrm{ER} \mathrm{Ca}^{2+}$ stores, reducing the interaction of F508del-CFTR with calnexin. In addition, roscovitine lowers proteasomal activity in a $\mathrm{Ca}^{2+}$-independent manner. Altogether, this favors the stabilization of F508del-CFTR and its trafficking to the plasma membrane.

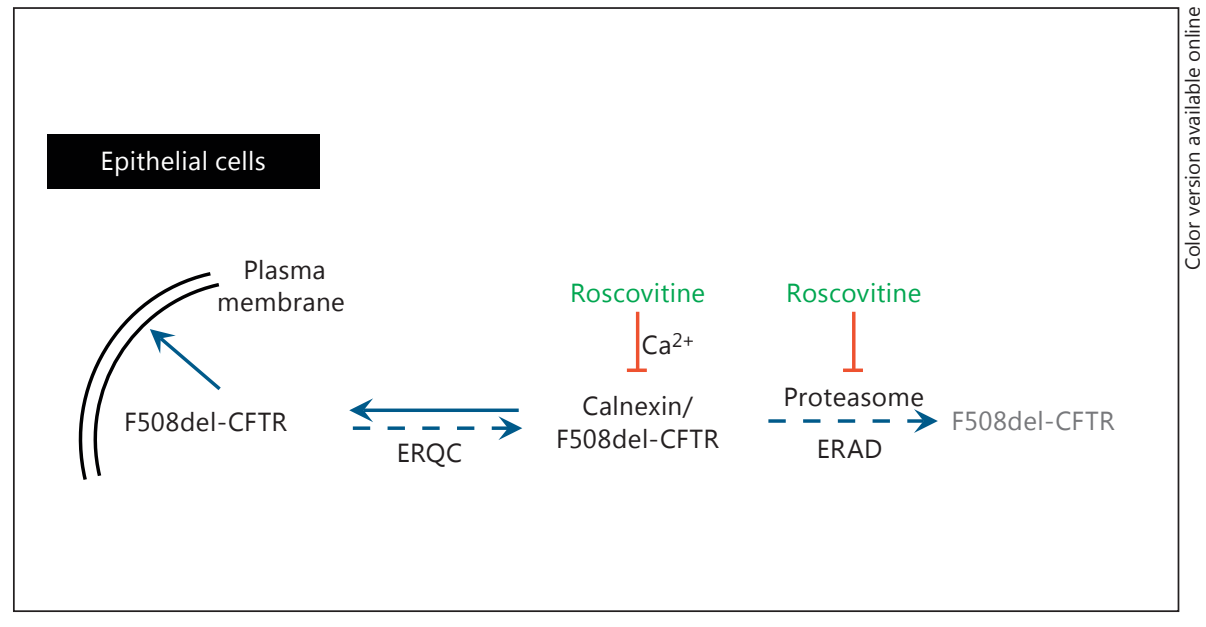

brane of epithelial cells. The mutation is temperature sensitive, meaning that physiological activity of F508delCFTR is partially restored when cells are cultured at a low temperature $\left(27^{\circ} \mathrm{C}\right)$. This is probably linked to proper folding, partial restoration of trafficking and correct translocation to the plasma membrane. The F508delCFTR protein is, thus, potentially functional but, at physiological temperatures, deletion of F508 prevents the correct folding and subsequent correct localization of CFTR to the plasma membrane. Correctors are usually lowmolecular-weight molecules that allow the localization of F508del-CFTR to the plasma membrane. Correctors are diverse in terms of chemical structure, mechanism of action and potency to rescue the abnormal trafficking and function of F508del-CFTR. However, all of these compounds are only partial correctors [15-19]. We have recently shown that roscovitine also acts as a partial corrector of F508del-CFTR [78]. This corrector effect seems to originate both from a negative effect on the recognition of F508del-CFTR by the endoplasmic reticulum (ER) conformation-based quality control pathway and from a partial inhibition of F508del-CFTR proteolysis by the ERassociated degradation pathway (fig. 2). Depletion of ER $\mathrm{Ca}^{2+}$ stores by roscovitine reduces the $\mathrm{Ca}^{2+}$-dependent interaction of F508del-CFTR with calnexin, preventing F508del-CFTR to be taken up by the ER-associated degradation pathway to proteolysis. In parallel, roscovitine reduces proteolytic degradation of F508del-CFTR by the proteasome in $\mathrm{Ca}^{2+}$-independent manner. This increases the availability of F508del-CFTR for translocation to the plasma membrane (fig. 2). The resulting corrector effect does not require the kinase-inhibitory activities of roscovitine as M3, the main hepatic metabolite of rosco- vitine (fig. 1) [73, 77], also displays corrector properties. Furthermore, other roscovitine derivatives which are active on kinases (CR8, olomoucine) do not show a corrector activity. Recently, a screen to detect potential correctors among a chemical library of 231 kinase inhibitors revealed several corrector products (active at $10 \mu \mathrm{M}$ ), notably kenpaullone and alsterpaullone, two inhibitors of CDK/GSK-3 [80]. These compounds, which we also identified as correctors [unpubl. results], were developed during a long-term collaboration between our laboratory in Roscoff and Prof. Conrad Kunick's team in Braunschweig [81].

\section{Roscovitine Reduces the Intraphagolysosomal pH} in CFTR-Deficient Macrophages and Restores Their

Bactericidal Properties

For several years, treatment of CF has aimed at correcting the epithelial defect due to CFTR absence or dysfunction. Several lines of evidence are converging to a novel paradigm of a dysregulated innate immunity resulting in the defects in bacterial clearance observed in CF [7-12]. Pivotal to these processes are neutrophils and macrophages [12].

Intraphagolysosomal $\mathrm{pH}$ and Bactericidal Abilities of Macrophages

The intraphagolysosomal $\mathrm{pH}$ of CFTR-deficient or cftr-/- macrophages has been shown to be abnormally high ( $\mathrm{pH}$ 6.5-7.2) when compared to the intraphagolysosomal $\mathrm{pH}$ of non-CF macrophages ( $\mathrm{pH} 4.5-5.2$; fig. 3a, b) [82]. Neither the phagocytic capacity of macrophages nor the fusion of phagosomes with lysosomes are affected by the mutant CFTR [82]. However, bacteria, once phagocy- 


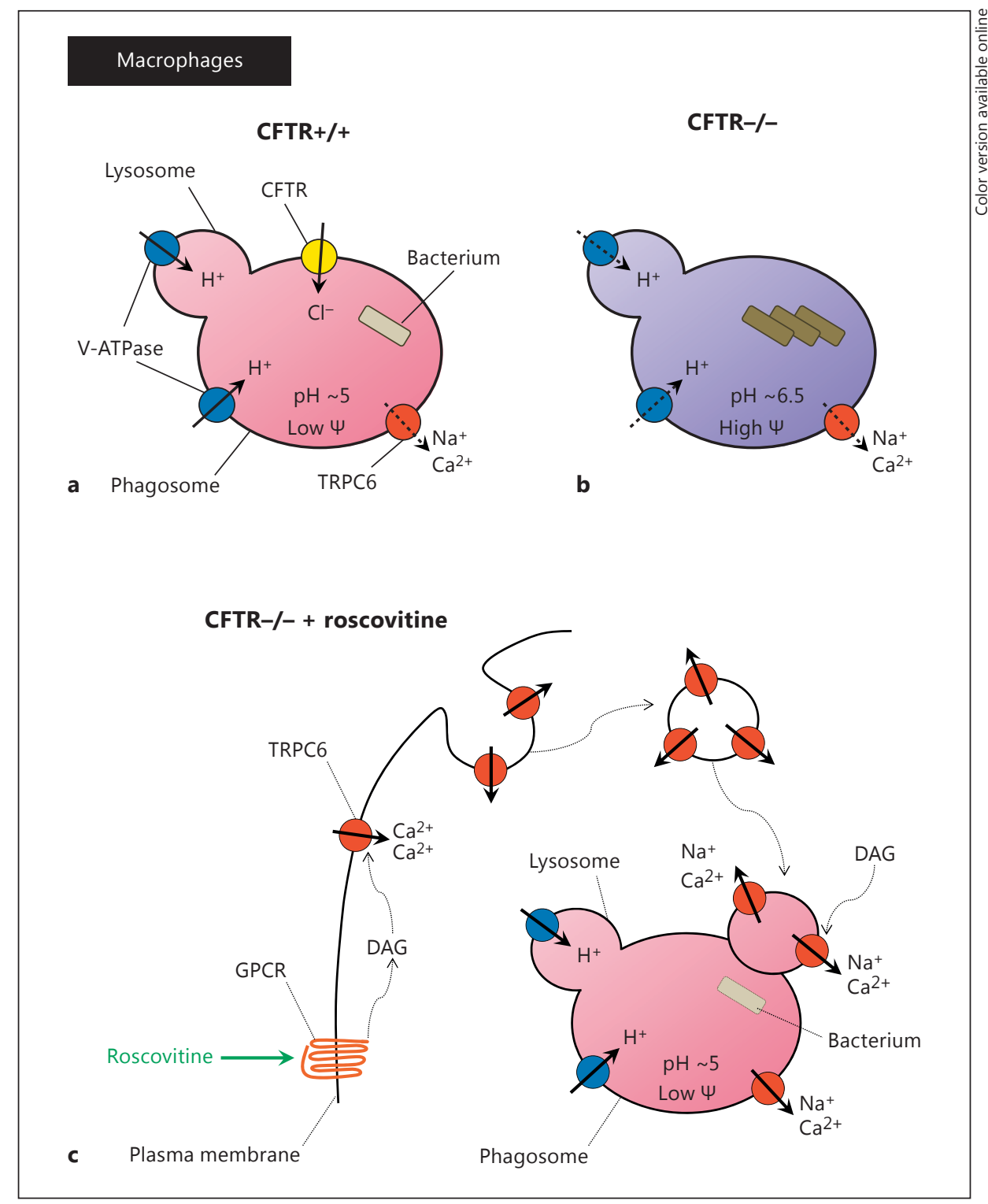

Fig. 3. Schematic overview of TRPC6 rescue of microbicidal activity in CFTR-deficient AMs through GPCR (G protein-coupled receptor) activation with (R)-roscovitine. Ionic fluxes in alveolar phagosomal membranes are permissive for intraluminal acidification and the development of a microbicidal environment. GPCR stimulation with (R)-roscovitine sets sequential intracellular signaling events in motion, leading to vesicle-mediated TRPC6 translocation and insertion. Calcium-dependent TRPC6 insertion into the plasma membrane and subsequent uptake into phagosomes determines the production of an intraluminal microbicidal environment. a CFTR+/+ AMs. Phagosomal acidification is driven by the flow of protons into the phagosomal lumen through V-ATPase activity, which, if uncompensated, produces charge buildup in the confined intraluminal compartment. Charge compensation is provided by $\mathrm{Cl}^{-}$influx through CFTR allowing for a decrease in phagosomal membrane potential and enhanced acidification. The phagosomal lumen $\mathrm{pH}$ is approximately 5 , and the phagosomal membrane potential $(\Psi)$ is low (approx. $+28 \mathrm{mV}$ ). The acidified phagosomal lumen supports the proteolytic activity of lysosomal enzymes, leading to bacterial killing. b CFTR-/- AMs. The absence of a $\mathrm{Cl}^{-}$influx pathway reduces the level of acidification, and the phagosomal lumen $\mathrm{pH}$ reaches near-neutral levels, leaving a high phagosomal membrane potential. The lack of an acidified phagosomal lumen prevents bacterial lysis and supports bacterial growth. The elevated phagosomal membrane potential reduces proton movement into the phagosomal lumen. c CFTR-/- AMs exposed to roscovitine. Recruitment of the cation channel TRPC6 to the plasma membrane and subsequently to the phagosomal membrane upon particle engulfment provides an alternative charge shunt pathway in the absence of CFTR expression. Activation of TRPC6 in the phagosomal membrane by (R)-roscovitine-generated diacylglycerol (DAG) opens a cation exit pathway from the phagosomal lumen acting as an alternate charge shunt, thereby allowing for $\mathrm{pH}$ regulation and acidification. The phagosomal $\mathrm{pH}$ is maintained at a level of approximately 5 and the membrane potential is low. These conditions support microbicidal activity [adapted from 79]. 
tosed, are not destroyed in the phagolysosomes $[82,83]$. Bacteria are even able to multiply within the phagolysosomes [83], which sit at neutral $\mathrm{pH}$ far from the normal acidic $\mathrm{pH}$ optimum for lysosomal lipases and proteases. As a consequence, the inability of F508del-CFTR macrophages to destroy bacteria can aggravate infections that affect $\mathrm{CF}$ patients. Elevation of intraphagolysosomal $\mathrm{pH}$ by 2 units is also observed in $c f t r-/-$ macrophages which completely lack expression of this ion channel.

The $\mathrm{pH}$ abnormalities in $\mathrm{CF}$ are now being documented in different cellular compartments, cells and tissues [82-89] despite earlier resistance in certain camps [9094]. Recent findings from Zhang et al. [88] identified a population of secretory lysosomes that exhibit a higher $\mathrm{pH}$ in alveolar macrophages (AMs) deficient in $\mathrm{cftr}-/-$ than in wild-type lung macrophages. The role of CFTR in bacterial clearance in the lung is underscored in recent studies on CF pigs which develop human-like CF lung disease [95-97]. Newborn pigs do not exhibit signs of airway inflammation but already display a defect in their ability to eliminate bacteria, which leads to the accumulation of bacteria in the lungs [reviewed in 98]. These studies provide further validation for our data which established that AMs express functional CFTR and cells from CFTR null as well as mutant mice exhibit defective bactericidal activity $[82,86]$. The cause of this deficiency is apparently a failure of lysosomes and phagosomes to acidify properly in the knockout model. The severity of the acidification phenotype scales with the mutant genotype with F508del-CFTR being the most severe [86]. Phagocytosis per se is not affected and it does not appear that CFTR affects phagolysosomal fusion or reactive oxygen species production. Interestingly, only AMs showed a dependence of lysosomal acidification upon CFTR expression. Recently published data demonstrate that the macrophage tissue source determines dependence of intracellular acidification on CFTR expression [86]. We surmise that other $\mathrm{Cl}^{-}$channels may play a similar role in phagosomal function in other innate immune cells. Mice null for CLC-3 are susceptible to sepsis, and Moreland et al. [99] suggested that CLC-3 is crucial for normal host defense by mechanisms that may involve phagocytic and secretory behavior in neutrophils, observations which are in conflict with those of Painter et al. [100-102], who maintained that CFTR mediates halide transport in human neutrophils.

In collaboration with ManRos Therapeutics, the University of Chicago group (V.R., A.G.G. and D.N.) demonstrated that roscovitine reduces the intraphagolysosomal $\mathrm{pH}$ of F508del-CFTR macrophages by more than 1 unit (fig. 3c). This effect is also observed with the M3 metabolite of roscovitine. We initially thought that roscovitine was acting as a corrector in F508del-CFTR AMs with the F508del-CFTR being addressed to the phagolysosome membranes following uptake of the bacterial cargo, and thus correcting the intraphagolysosomal $\mathrm{pH}$. Unexpectedly, roscovitine also reduced the intraphagolysosomal $\mathrm{pH}$ of cftr-/- macrophages. This demonstrates that the CFTR channel is not involved in the acidifying effect of roscovitine in phagolysosomes. This effect could thus, in principle, take place in any macrophage that shows a neutral intraphagolysosomal $\mathrm{pH}$ linked to a functional inactivation of CFTR, in other words independently of the mutation involved. In terms of therapeutic applications, this signifies that roscovitine could, therefore, have a macrophage phagolysosomal $\mathrm{pH}$-correcting effect in many forms of $\mathrm{CF}$, regardless of the mutation affecting the CFTR gene and channel functionality.

The consequence of the intraphagolysosomal $\mathrm{pH}$ rescue, even if partial, is a marked improvement in the ability of $c f t r-/-$ and F508del-CFTR macrophages to eliminate $P$. aeruginosa, the major pathogen in CF (fig. 4). Improvement in the bactericidal properties of these macrophages lacking CFTR or functional CFTR, by treatment with roscovitine, is therefore independent of CFTR and - perhaps more importantly - of the antibiotic resistance profile of bacterial isolates. Roscovitine could, therefore, have a general bactericidal effect on most CF forms. Improvement in the bactericidal properties is observed with the M3 metabolite, S-CR8, $\mathrm{N}^{6}$-methyl-roscovitine and $\mathrm{O}^{6}$-benzyl-roscovitine, but is not observed with S-roscovitine, miglustat, olomoucine, finisterine, perharidine or purvalanol A [79].

Molecular Mechanisms of Action: Indirect Targeting of the TRPC6 Ion Channel

Recent results suggest that the effects of roscovitine on the intraphagolysosomal $\mathrm{pH}$ of macrophages could be explained by an action mediated by the $\mathrm{Ca}^{2+}$-permeable channel TRPC6 [79]. TRPC6 belongs to the TRP (transient receptor potential) family of ion channels, particularly important in respiratory system diseases. The TRP family comprises 28 members, which are grouped into several different classes: TRPC (canonical), TRPV (vanilloid), TRPM (melastatin), TRPP (polycystin), TRPML (mucolipin) and TRPA (ankyrin) [reviewed in 103-108]. The TRPC channels comprise 6 members, TRPC1, TRPC 3 , TRPC4, TRPC5, TRPC6 and TRPC7. TRPC6 is a channel activated by diacylglycerol derived from the hydrolysis of phospholipids (phosphoinositides) by phospholipase C. 

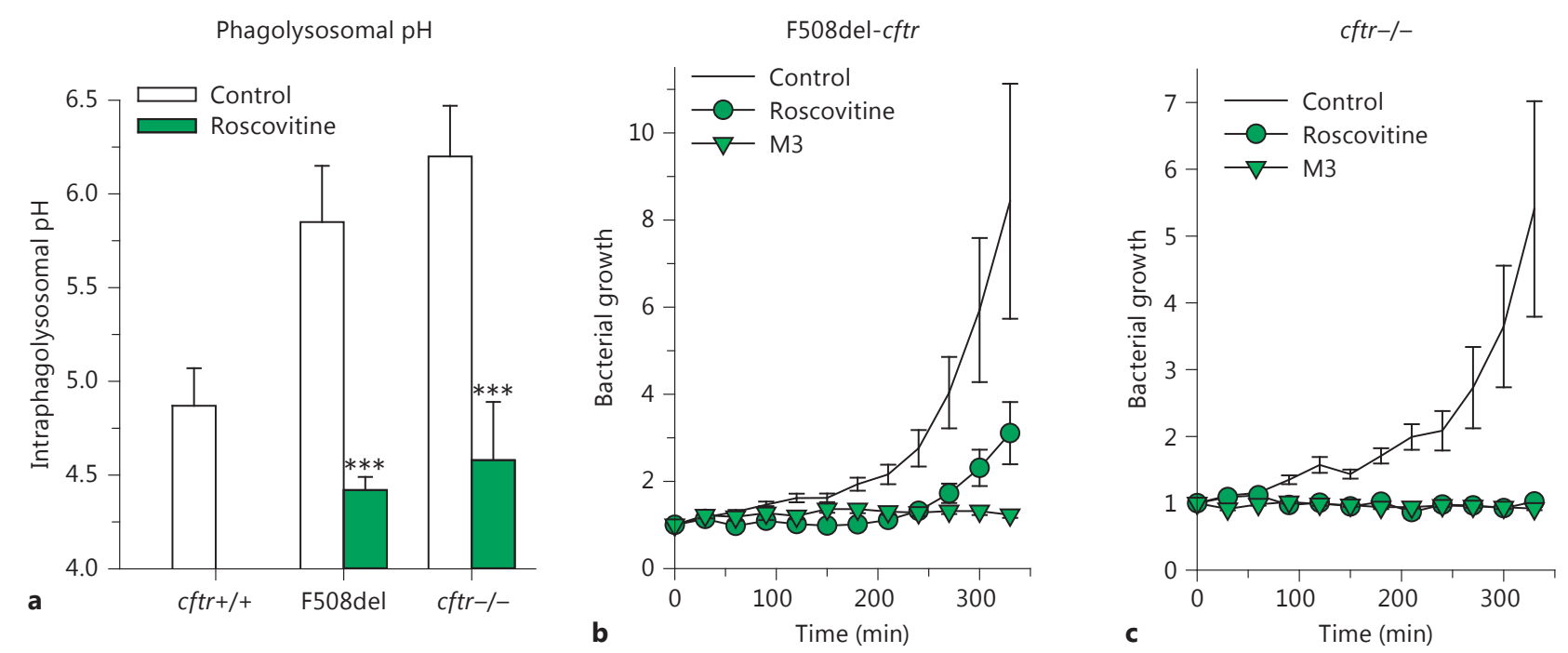

Fig. 4. Roscovitine acidifies the phagolysosomes of F508del-CFTR and cftr-/- macrophages and prevents bacterial growth (b, c). a Intraphagolysosomal $\mathrm{pH}$ in $c f t r+/+$, F508del-CFTR or $c f t r-/-$ mouse AMs. Mutation or absence of CFTR leads to increased $\mathrm{pH}$. Exposure to roscovitine results in phagolysosomal acidification. Means \pm SEM. ${ }^{* * *} \mathrm{p}<0.001$ vs. control (two-way ANOVA). b, c F508del-CFTR (b) or cftr-/- (c) AMs were exposed to DsRedlabeled bacteria, and fluorescence intensity at $607 \pm 20 \mathrm{~nm}$ was

TRPC6 is expressed in cells implicated in inflammation and innate immunity, neutrophils [109-111] and macrophages $[112,113]$. TRPC6 is highly expressed in the lungs. Its expression is increased in macrophages from patients with chronic obstructive pulmonary disease and pulmonary hypertension $[112,113]$. Activation of TRPC6 is implicated in pulmonary edema (lung ischemia-reperfusion-induced edema) [114]. Deletion of TRPC6 in mice (trpc6-/-) specifically inhibits pulmonary inflammatory reactions of allergic origin [115]. Few antagonists and agonists of TRPC6 have been described; they generally display low efficiency [116]. Hyperforin (from the St. John herb or St. John's wort) is an activator of TRPC6 [117]. A series of TRPC6 channel antagonists has been described by Sanofi [118]. Work by Antigny et al. [119, 120] suggested that TRPC6 activity is regulated by the CFTR channel. The physical interaction of the two channels leads to an inhibition of calcium entry through TRPC6. On the other hand, F508del-CFTR is unable to interact with TRPC6, and this would lead to excessive activation of monitored over time following exposure to $20 \mu \mathrm{M}$ roscovitine, M3 or corresponding amounts of vehicle (control). Bacterial growth is shown as fold increase in DsRed fluorescence. Summary data from at least 3 separate experiments [adapted from 79]. Mean fluorescence intensities \pm SEM. Bacterial growth is prevented by $c f t r+/+$ AM (data not shown), but not by F508del-CFTR or cftr-/- AM. Bacterial growth is prevented by both roscovitine and its metabolite.

TRPC6 and abnormal entry of calcium. The influx of calcium can be normalized once the trafficking of F508delCFTR is corrected (miglustat) or by anti-TRPC6 siRNA $[119,120]$. Our results show that roscovitine acts as an indirect activator of the TRPC6 channel, independently of CFTR channel expression or mutation. Roscovitine induces the production of diacylglycerol, which activates the translocation of TRPC6 calcium channels to the plasma membrane. Following phagocytosis, TRPC6 channels are integrated in the phagosomal membrane and contribute to cation depletion inside the phagolysosomes, thus amplifying intraphagolysosomal acidification due to vacuolar-type (V)-ATPase (which, by hydrolyzing ATP, allows proton entry). This effect is responsible for the intraphagolysosomal acidification of macrophages (fig. 3c).

\section{Roscovitine Displays Anti-Inflammatory Properties}

Effects on Neutrophils

Neutrophils represent the first line of defense against microbes but are also powerful proinflammatory cells 
Fig. 5. Roscovitine and neutrophils. a The different steps of inflammation: initiation by neutrophil infiltration is followed by neutrophil apoptosis. Macrophage infiltration then allows phagocytosis of apoptotic neutrophils and resolution of inflammation [adapted from 159]. Neutrophils from CF patients appear to be partially protected from apoptosis. Roscovitine induces apoptosis of neutrophils, improving their elimination by macrophages and thus favoring the resolution of inflammation. $\mathbf{b}$ Proposed molecular mechanisms underlying induction of apoptosis by roscovitine [adapted from 36]. The cell survival/cell death balance is maintained by Mcl-1, a Bcl-2 family member survival factor that binds to and neutralizes proapoptotic proteins such as Noxa. Mcl-1 is a short-lived protein being constantly synthesized (through RNA polymerase 2, itself under the control of CDK7/ cyclin $\mathrm{H}$ and $\mathrm{CDK} 9 /$ cyclin $\mathrm{T}$ ) and constantly degraded (through Mcl-1 ubiquitin ligase and proteasome). Roscovitine inhibits CDK7 and CDK9, preventing phosphorylation of RNA polymerase 2 at Ser-2 and Ser-9, respectively. Consequently, mRNA synthesis is transiently inhibited, and short-lived mRNAs and proteins are down-regulated. This is the case for Mcl-1. Reduction in the Mcl-1 protein level results in a transient increase in free Noxa protein, which triggers Bax/Bak-dependent apoptotic cell death.

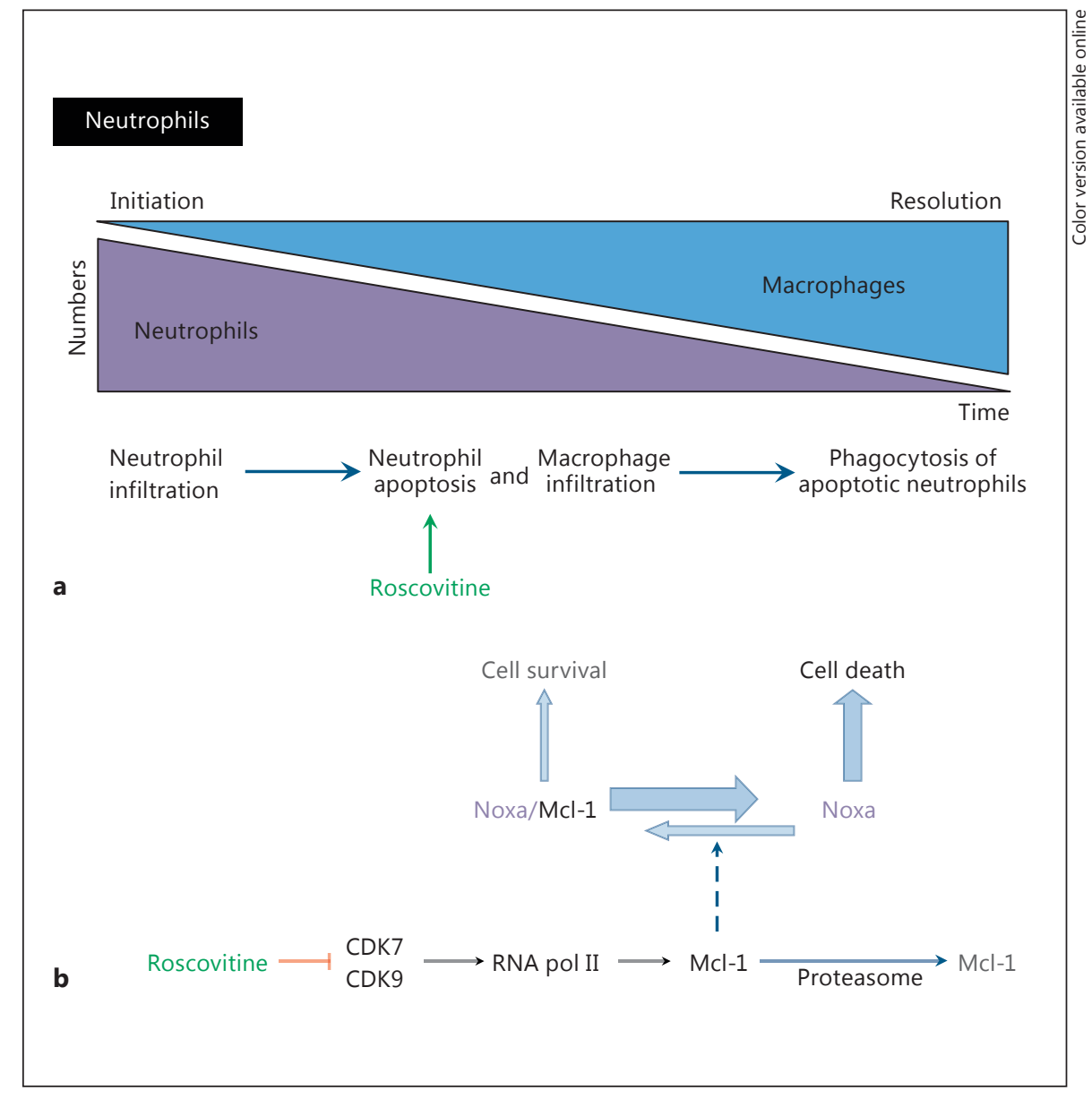

able to injure host tissue (fig. 5a). CF constitutes a representative example of a pathogenic condition in which the deleterious power of neutrophils is at work, with uncontrolled activated neutrophils unable to kill invading bacteria [121]. This particular picture has led to a still unresolved neutrophil conundrum in CF, i.e. whether neutrophils could be genetically modified to display such a proinflammatory phenotype [9]. Indeed, as in macrophages [89] and monocytes [122], CFTR is expressed in neutrophils and regulates bactericidal activity $[101,123-$ 125].

Neutrophil extracellular traps (NETs) contribute to inflammation in a number of diseases, such as systemic lupus erythematosus [126] and inflammatory arthritis [127], and have been described in CF [128-130]. Furthermore, $P$. aeruginosa can induce NETosis $[127,131-$ 134]. Oxidative burst and NADPH oxidase activity are central to the process of NET formation, with myeloperoxidase and neutrophil elastase acting as essential cofactors $[135,136]$. The importance of NETs in the killing of pathogens is a matter of concern and has recently been challenged by a report showing that neutrophils from patients with the Papillon-Lefèvre syndrome lacking serine proteinases and unable to produce NETs did not show any defect in bacterial killing [137]. Oxidative burst causes downstream activation of peptidyl dearginase (PAD4), which in turn translocates to the nucleus and hypercitrinulates histones, leading to nuclear decondensation [138]. NETosis is entirely distinct from apoptosis [139] but may involve the activation of autophagic pathways $[140,141]$. The clearance of NETs, unlike that of apoptotic neutrophils, is poorly understood, with undegraded NET fragments promoting inflammation in systemic lupus erythematosus [142]. As such, the proinflammatory potential of NETs in the CF airway cannot be ignored.

A complex relationship exists between infections and inflammation in the lungs of CF patients [reviewed in 17, 143-146]. The persistence of neutrophils in CF lung that failed to clear bacterial infection and are not cleared 
themselves by macrophages following apoptosis strongly points to the importance of innate immune cells in this process in CF. Furthermore, other forms of neutrophil death, such as NETosis, may be prevalent in the CF lung and contribute to lung damage and bacterial colonization $[147,148]$. Of note is the modulation of immune responses to infections by proteases from neutrophils, especially through chemokines [149].

Through several structural and pharmacological properties, roscovitine targets innate immune cells via different mechanisms. The discovery that CDK inhibitors, such as roscovitine, could indeed favor the disposal of neutrophils by enhancing both their apoptosis and their phagocytosis by macrophages has opened a promising research field [74, reviews in 150, 151]. Roscovitine resolves the inflammatory response in various animal models $[74,150]$. This activity is linked to the proapoptotic action of roscovitine on neutrophils (fig. 5a). The molecular mechanism is likely to implicate inhibition of CDK7 and CDK9 [152], which leads to reduced expression of the cell survival and anti-apoptotic factor Mcl-1 $[153,154]$, an effect we have also observed while analyzing the anticancer activity of roscovitine and its derivatives (fig. 5b) [155]. Roscovitine also inhibits the production of nitric oxide and inhibits the activation of NFKB in macrophages $[156,157]$. Inhibition of the NFKB pathway by CR8, an analogue of roscovitine, was also observed in chronic lymphocytic leukemia cells [158]. The anti-inflammatory effect of roscovitine via enhanced apoptosis of neutrophils was confirmed in a zebrafish inflammatory model $[159,160]$, a mouse model with pulmonary inflammation induced by S. pneumoniae and lipoteichoic acid (a proinflammatory constituent of Gram-positive bacteria) [75], a mouse model of ventilator-induced lung injury [76] and an experimental mouse model of pneumococcal meningitis [161]. It was also shown that roscovitine, by inhibiting CDK2 and CDK5, blocks endothelial activation and leukocyte/endothelial cell interactions, contributing to the anti-inflammatory effect [162]. One of the specificities of CF is the persistence of an enormous burden of neutrophils in the airways [163, 164 , reviewed in 165,166$]$. In spite of the overabundance of neutrophils, the deficit in antimicrobial activity results in a chronic $P$. aeruginosa infection suggesting defective innate immunity $[9,10,166-168]$. In vitro studies show that the apoptotic death of neutrophils from CF patients is delayed, thus impairing their elimination by macrophages and promoting inflammation [169-171]. The in vitro kinetics of apoptosis is slowed down in neutrophils from CFTR mutation heterozygote parents, as seen with neutrophils of their children (homozygotes) [171]. In vitro, roscovitine restores a normal level of apoptosis in neutrophils isolated from CF patients [171]. Roscovitine-induced apoptosis of neutrophils and their progenitors has been linked to the Noxa-dependent degradation of Mcl-1, which liberates Bim and Puma, two activators of the proapoptotic factor Bax [172], which, interestingly, has been demonstrated to be deficient in CF [173]. Furthermore, roscovitine inhibits the proliferation of those progenitor neutrophils which managed to escape apoptosis [161].

The spectrum of biological activities of roscovitine is wide and, importantly, appears to be cell specific. For instance, the proapoptotic effect in neutrophils is extremely effective, while no such effect is observed in macrophages. Roscovitine effects should, thus, be studied in each cell type and might also depend on the type of CFTR mutation.

\section{Effects on Eosinophils}

In addition to neutrophils, eosinophils may participate to lung tissue injury in CF $[174,175]$. The pathophysiological importance of eosinophils may be specifically relevant in CF patients showing allergic bronchopulmonary aspergillosis [176].

Upon stimulation, eosinophils release the content of their secretory granules, which comprise various toxic proteins, such as eosinophil cationic protein (ECP) and eosinophil peroxidase (EPX), and produce proinflammatory mediators, such as leukotrienes $\left(\mathrm{LTC}_{4}\right)$. Although their number remains stable in the peripheral blood and lung, eosinophils are activated in CF [177, 178], resulting in enhanced production of ECP and EPX [175-179] and $\mathrm{LTC}_{4}$ [180] compared to healthy controls. Eosinophils isolated from CF patients release higher amounts of ECP than those of control, healthy patients [181]. ECP levels found in the sputum of CF patients reach levels similar to those able to induce pulmonary damage in vitro [179181] and correlate with ions levels [182].

Eosinophils express various CDKs, CDK5 in particular $[183,184]$, and its activating partners p35 and p39 [185]. Upon eosinophil stimulation, CDK5 is phosphorylated on Ser-159, and its catalytic activity is increased [184]. This correlates with phosphorylation of one of its substrates, Munc-18 [184-186], release of syntaxin-4 and its binding to SNARE proteins (soluble N-ethylmaleimide-sensitive factor attachment protein receptors). The binding of syntaxin-4 to SNARE proteins allows interaction of vesicular R-SNAREs to plasma membrane Q-SNAREs, subsequent membrane fusion and 
Fig. 6. Roscovitine and eosinophils. Proposed molecular mechanisms underlying the action of roscovitine on eosinophils. Under resting conditions, Munc-18 binds to syntaxin-4, preventing it from interacting with SNARE proteins. During inflammation, CDK5 catalytic activity is increased, leading to Munc-18 phosphorylation (p) and preventing the binding of syntaxin-4 to Munc-18. Syntaxin- 4 is then free to bind SNAREs, allowing the fusion of intracellular granules to the plasma membrane and release of their contents (e.g. EPX, ECP and $\mathrm{LTC}_{4}$ ) in the extracellular space. Roscovitine, by inhibiting CDK5, prevents the release of syntaxin-4 from Munc-18 and binding to SNAREs. Consequently, exocytosis is inhibited.
Eosinophils

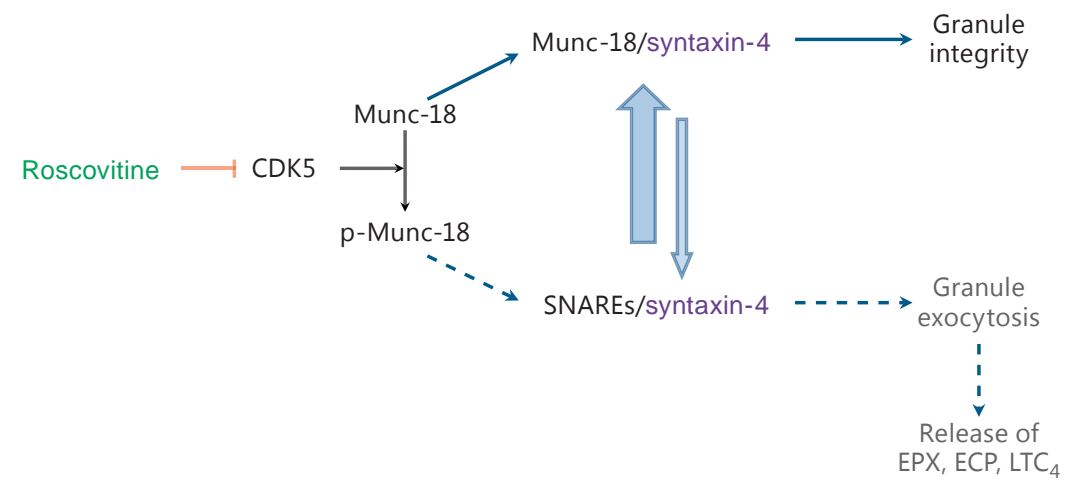

exocytotic degranulation [184]. Pharmacological inhibitors of CDKs, such as roscovitine and AT7519, or CDK5 siRNA, reduce EPX release by eosinophils activated by PMA (phorbol 12-myristate 13-acetate) or secretory IgA [184]. These results suggest that roscovitine, by inhibiting CDK5, may reduce degranulation of challenged eosinophils (fig. 6).

Finally, roscovitine also induces apoptosis (assessed by several techniques) of activated human eosinophils in vitro by reducing Mcl-1 expression [187], possibly by a mechanism involving inhibition of CDK7 and/or CDK9 [188]. Whether roscovitine, other CDK inhibitors or other agents that drive eosinophil apoptosis enhance the resolution of eosinophilic-dominant inflammation in vivo is under intense investigation $[189,190]$.

Altogether, these data suggest that roscovitine may reduce the number and secretory activity of eosinophils, an effect which is expected to be potentially beneficial to $\mathrm{CF}$ patients if seen in vivo.

\section{Effects on T Lymphocytes}

CD4+ T-helper (Th) cells play a major role in immune responses. Once activated by antigens, these cells differentiate into different cell types, typically Th1 and Th2 lymphocytes, but also Th17 cells and iTregs (induced regulatory T cells; fig. 7). Proinflammatory Th17 cells are characterized by the production of IL-17A and play an important role in autoimmune diseases, cancer and elimination of extracellular bacteria. On the other hand, antiinflammatory Treg cells play a key role in controlling immunological tolerance and in suppressing excessive immune responses deleterious to the host. There is an intricate link between iTreg and Th17 cell programs of dif- ferentiation, which both require TGF- $\beta$ (transforming growth factor- $\beta$ ). Upon activation in the presence of TGF- $\beta$, naive CD4+ T cells (Th0) can differentiate into either Th17 or iTreg cells, depending on the overall cytokine milieu [191]. Low or intermediate concentrations of TGF- $\beta$ together with proinflammatory cytokines (IL-6, IL-1 $\beta$ and IL-23) promote the differentiation of Th17 cells through expression of the nuclear receptor ROR $\gamma \mathrm{t}$ (retinoic acid-related orphan receptor). Such activation inhibits the expression and function of Foxp3, the transcription factor driving the Treg differentiation program. Conversely, in the absence of proinflammatory cytokines, high levels of TGF- $\beta$ promote the expression of Foxp3 and differentiation of iTreg cells. This process is further enhanced by IL-2 and retinoic acid, and is associated with inhibition of ROR $\gamma \mathrm{t}$ expression and function. Th17 and iTreg cells thus reciprocally inhibit their differentiation (fig. 7) [192, 193].

Emerging evidence suggests that an imbalance of Tcell responses may contribute to CF pathophysiology. A role for the Th17 and Th2 T lymphocytes in chronic pulmonary inflammation in CF patients was recently proposed. Th0 cells from CF patients or mice show a predisposition to differentiate towards the proinflammatory Th17 phenotype, while normally having a propensity to differentiate into Th1 and Treg lineages [194]. High peripheral blood Th17 levels are associated with poor lung function in CF [195]. A specific profile of proinflammatory cytokines/chemokines (particularly IL-17A and IL5) may be a risk factor for $P$. aeruginosa infection [196]. A link between the inflammatory background mediated by $\mathrm{T}$ cells and susceptibility to $P$. aeruginosa infection remains to be shown. IL-17A plays a major role in the 
Fig. 7. Roscovitine and lymphocytes. Depending on external stimuli, CD4+ Th0 cells differentiate into Th1 (IL-12), Th2 (IL-4), Th17 (TGF- $\beta$, IL-6, IL- $1 \beta$ and IL23 ) and iTreg (TGF- $\beta$, IL-2 and retinoic acid) lymphocytes. The relative amounts of TGF- $\beta$, interleukins, retinoic acid and additional cytokines skew the differentiation of Th0 cells into either highly proinflammatory Th17 (through ROR $\gamma \mathrm{t}$ ) or antiinflammatory iTreg (through Foxp3) cells. Possibly through inhibition of CDKs and DYRK1A, roscovitine inhibits the differentiation into Th17 cells, lowering the production of proinflammatory interleukins (IL-17A, IL-17F, IL-21 and IL-22). Consequently, the balance of Th17/iTreg shifts towards the anti-inflammatory response.

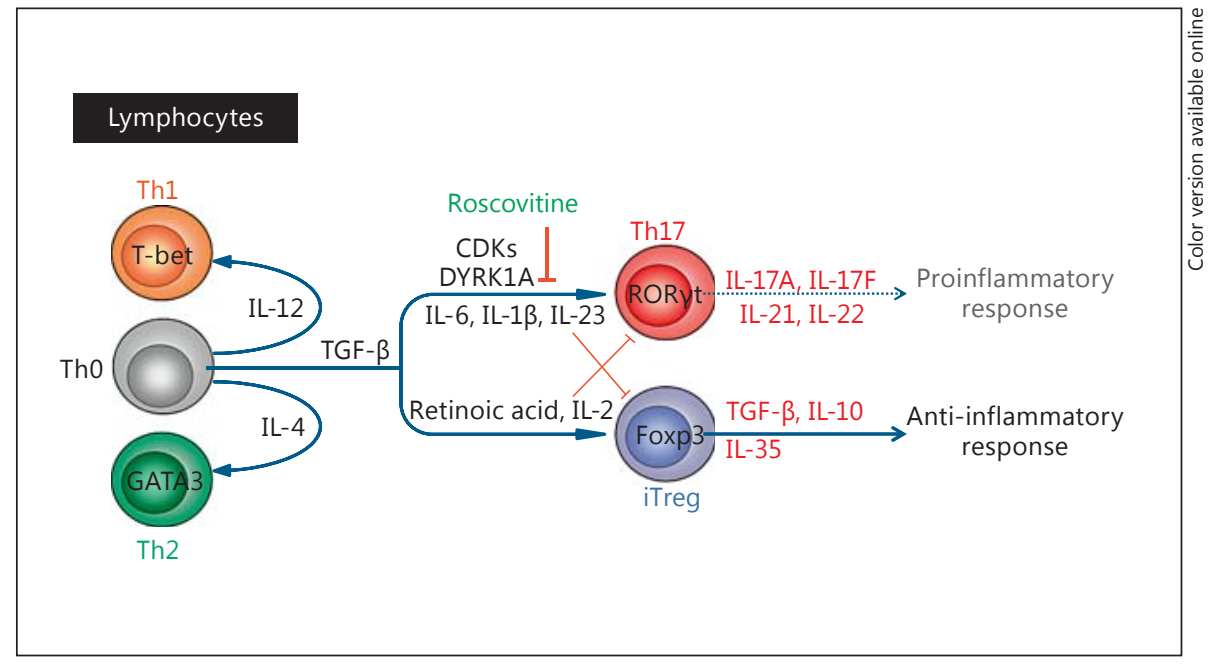

recruitment, activation and migration of neutrophils in CF patients [197], its expression is increased in CF patients' sputum [198] and its overproduction has even been suggested as the cause of chronic lung inflammation in CF patients $[199,200]$. Expression of IL-17 could serve as an early biomarker for $P$. aeruginosa infection [196]. A robust increase in Th17 lymphocytes (proinflammatory) together with enhanced Th2 responses and a decrease in Treg lymphocytes (anti-inflammatory), observed in cftr-/- mice, was coupled to susceptibility to infection by Aspergillus fumigatus. A reduction in the expression of indoleamine 2,3-dioxygenase (IDO), the first enzyme in the tryptophan degradation pathway, was observed in CF patients and in the cftr-/- mouse model. The imbalance of Th17 versus Treg is linked to the reduction in IDO activity. Inhibition of Th17 activation (IL17A siRNA) or stimulation of the IDO pathways (kynurenines) restores protection against A. fumigatus [200]. Heightened Th2 responses in CF patients with allergic bronchopulmonary aspergillosis were associated with lower frequencies of Tregs compared with A. fumigatus-colonized CF patients without allergic bronchopulmonary aspergillosis [201]. A previous report suggested significantly lower percentages of circulating Tregs in children with CF, and a correlation between decreased frequencies of Tregs and lower $\mathrm{FEV}_{1}$ [202]. A recent study further showed that patients with CF who have chronic $P$. aeruginosa infection show an age-dependent, quantitative and qualitative impairment in Tregs. Tregs isolated from CF patients or from cftr-/- mice showed reduced functional suppressive activity compared with Tregs from non-CF controls. Both 'extrinsic' $P$. aeruginosa-induced effects and 'intrinsic' CFTR-me- diated Treg functional skewing contributed to Treg impairment in CF [203]. Th17 cells, through IL-17 production, may also be involved in CF-related diabetes [204]. The involvement of T lymphocytes in CF is presented in two brief reviews $[205,206]$.

Several articles have described the effects of roscovitine on T lymphocytes [207-209]. A screen of 256 inhibitors of intracellular signaling pathways has led to the identification of CDK inhibitors, and roscovitine in particular, as suppressors of Th17 differentiation and, thus, as activators of iTreg differentiation [207]. Induction of iTreg cell differentiation by CDK2 inhibition was recently confirmed with kenpaullone, another pharmacological inhibitor of CDKs [210]. Another essential kinase regulating the differentiation of Th17 and Tregs is DYRK1A [211]. Inhibition of DYRK1A enhances Treg differentiation, impairs Th17 differentiation and attenuates inflammation [211]. As roscovitine is also a DYRK1A inhibitor ( $\mathrm{IC}_{50}$ in the $\mu \mathrm{M}$ range) $[34,212]$, its effect on DYRK1A may contribute to its effects on T-cell differentiation. In a mouse model, roscovitine ameliorates experimental autoimmune encephalomyelitis, an autoimmune disease mediated by Th17 cells [207]. Roscovitine suppresses CD4+ Th cells and has a beneficial effect on a uveitis mouse model, an autoimmune disease [208]. Roscovitine decreases the production of proinflammatory interferon and IL-17 [208], confirming previous results [209]. Roscovitine thus modifies the Th17/Treg balance in a favorable, anti-inflammatory direction (fig. 7). Whether roscovitine displays additional direct effects that may mitigate CFTR-dependent intrinsic functional skewing of Tregs remains to be determined. 


\section{Roscovitine Has Analgesic Properties}

Pain is a common event in CF [213, 214]. Among several CDKs, roscovitine inhibits CDK5, a kinase activated by the binding of one of the regulatory subunits (p35 or p39) and their respective proteolytic fragments (p25 or p29). CDK5 is known to be involved in modulating pain signaling [review in 215]. CDK5 is mostly expressed in the nervous system, namely sensory neurons of dorsal root ganglia (DRG), spinal cord and trigeminal ganglia [216218], and its expression as well as activity is significantly increased upon pain sensation. Roscovitine exhibits analgesic properties in various animal models of pain. Wang et al. [219] were the first to carry out behavioral studies based on the antinociceptive properties of roscovitine. Subsequent studies revealed the efficacy of roscovitine in attenuating peripheral inflammation induced by complete Freund's adjuvant (CFA). The subcutaneous injection of CFA evokes local inflammation, redness, swelling and hypersensitivity to noxious stimuli (hyperalgesia) that, subsequently, activate protein kinases like CDK5 in primary sensory neurons. Roscovitine treatment significantly reverses heat hyperalgesia induced by intraplantar CFA injection [218, 220-223]. The analgesic effects of roscovitine can occur through inhibition of CDK5 activity, decreased p35 expression [218] and/or reduced CDK5 phosphorylation at S159 by ERK MAP kinase, a posttranslational modification that promotes CDK5 activity [223]. Roscovitine can also affect CFA-induced inflammatory pain by suppressing TrkB (tropomyosin receptor kinase B) levels [222], reducing synaptophysin expression [221] and by preventing trafficking of TRPV1, an ion channel known to be involved in the detection of noxious heat, to the plasma membrane $[224,225]$. The level of CDK5 activity can also affect heat hyperalgesia from acute inflammation induced by carrageenan [216], and inhibition of CDK 5 by roscovitine in cultured DRG neurons attenuates calcium influx through TRPV1 [226].

Recent reports have also demonstrated the antinociceptive effects of roscovitine in neuropathic pain models. Significantly increased expression of CDK5 is observed in the dorsal horn of rats following chronic constriction injury of the sciatic nerve, and intrathecal delivery of roscovitine significantly attenuates mechanical allodynia in these rats [227]. Roscovitine can down-regulate expression of the NR2A receptor, which, in turn, can alleviate neuropathic pain caused by chronic DRG compression [228]. Additionally, roscovitine prevented remifentanilinduced postoperative thermal and mechanical hyperalgesia by decreasing expression and activity of CDK5/p35 and phosphorylation of NR2A (S1232), NR2B (Y1472) and mGlur5 (S1167) [229]. Roscovitine can also downregulate NMDA (N-methyl-D-aspartate) receptors in animal models of cancer pain, where roscovitine treatment significantly reduced mechanical allodynia and thermal hyperalgesia by inhibiting the NR2B receptor [230]. Additional evidence indicates that roscovitine promotes analgesia through of DARPP-32 dephosphorylation (T75) in a formalin-induced model of nociception [231]. Interestingly, CDK5 is found to be involved in cross-organ reflex sensitization and colon irritation caused an increase in CDK5 expression in the spinal cord and DRG. Intrathecal injection of roscovitine attenuates cross-organ sensitivity and colon irritation by decreasing NR2B phosphorylation [232].

All of these studies indicate promising analgesic effects of roscovitine in different animal models of pain. The antinociceptive properties of roscovitine along with its antiinflammatory effects may prove helpful in developing effective treatments of pain in CF patients.

\section{The 'Weaknesses' of Roscovitine}

Beside its properties in favor of its evaluation as a CF drug candidate, roscovitine has a few weaknesses, which can be summarized as follows. First of all, it was not optimized for this specific indication, in particular for its effects on macrophage intraphagolysosomal acidification. One can anticipate that identification of its molecular target(s) in macrophages - different from the usual kinase targets - should allow the optimization of much more potent and selective roscovitine analogues. Secondly, roscovitine was not optimized in terms of action on its anti-inflammatory targets. Analogues much more potent at inhibiting kinases are available, but, unfortunately, they are more toxic. Thirdly, roscovitine was not tested in animal models of CF. Despite their disputed predictive values, a positive effect would have been encouraging. Fourthly, roscovitine has a short half-life in human plasma. It remains, thus, to be seen whether sufficient lung biodistribution and exposure can be reached via the oral route. Possibly improved efficacy of roscovitine by administration through inhalation/nebulization has not been but should be evaluated. Despite these weaknesses, and considering its specific favorable properties and the benefits of drug repurposing in general, roscovitine has been favorably evaluated by official institutions to enter a first clinical trial which will both investigate tolerability in CF patients chronically infected with P. aeruginosa and possible beneficial effects [233]. 
Fig. 8. Summary of cellular effects of roscovitine which may be beneficial for the treatment of CF. Roscovitine acts independently on epithelial cells, macrophages, neutrophils, eosinophils and lymphocytes. Arrows: induction or enhancement; lines: inhibition or reduction.
Roscovitine effects

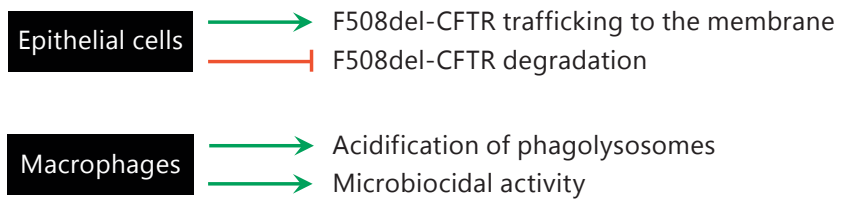

Neutrophils $\longrightarrow$ Apoptosis

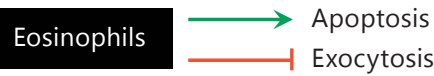

Lymphocytes $\longrightarrow$ Proinflammatory response

\section{Conclusion and Perspectives}

Evidence indicates that roscovitine has diverse biological properties that could potentially converge toward a novel treatment for CF (fig. 8): (1) roscovitine acts as a corrector of the F508del-CFTR channel by protecting it from proteolytic degradation, favoring its relocation in the plasma membrane; (2) roscovitine improves the bactericidal properties of macrophages from CF patients by translocating/activating the TRPC6 calcium channel (independently of the CFTR mutation) and by partially lowering the intraphagolysosomal $\mathrm{pH}$, which is abnormally elevated in CF macrophages; (3) its main hepatic metabolite also shows a F508del-CFTR corrector effect and biological activity on macrophages, despite extremely reduced kinase-inhibitory effects; (4) roscovitine has an anti-inflammatory effect likely originating from its ability to promote apoptosis in neutrophils and their elimination by macrophages; (5) roscovitine reduces degranulation of eosinophils and promotes their apoptosis; (6) roscovitine suppresses the differentiation of CD4+ Th cells into Th17 (proinflammatory lymphocytes, thus reducing the production of proinflammatory interleukins such as IL-17) and promotes their differentiation into Tregs (anti-inflammatory lymphocytes); (7) roscovitine displays analgesic properties, which could contribute to the management of CF-associated pain, and (8) roscovitine is an orally available drug which has already undergone preclinical pharmacological and toxicological studies, and extensive phase I and II clinical trials, in particular against lung cancer. Repurposing this anticancer drug candidate for CF should thus be a therapeutically valid proposal.

Besides direct clinical trials of roscovitine in CF patients, we foresee four main developments in this novel approach to CF. Firstly, the effects of roscovitine on CF models (organoids [234], ferret [235-237] and pig [95$98,237,238]$ models of CF and animal models of $P$. aeruginosa-induced infection $[238,239])$ should be investigated. Secondly, given the host-directed antibacterial effects of roscovitine, its action on other pulmonary pathogens associated with $\mathrm{CF}$, besides $P$. aeruginosa, [240-242], should be investigated. Thirdly, the expected long-term treatments required for $\mathrm{CF}$ and the multiple biological consequences of the disease call for serious consideration of combination treatment of roscovitine with other currently developed treatments and for alternative modes of administration. The recent combination therapy Orkambi ${ }^{\circledR}$ composed of the corrector lumacaftor (or VX809) and the potentiator ivacaftor (or VX770; www.vrtx.com) can now be prescribed to F508del homozygous CF patients [243]. It will thus be important to compare the combination of roscovitine/ivacaftor with lumacaftor/ivacaftor in a future study. Fourthly, the optimization and development of second-generation drugs derived from roscovitine, based on its CF-relevant molecular and cellular targets, should be envisaged. The chemistry and biology of purines in general [244, 245], and 2,6,9-trisubstituted purines in particular, have been extensively explored, providing a solid starting ground. 


\section{Acknowledgments}

This work was supported by the associations Vaincre la Mucoviscidose, ABCF Mucoviscidose, the LabEx INFLAMEX (ANR11-IDEX-0005-02), and the Chancellerie des Universités de Paris (Legs Poix; V.W.-S.) and National Institutes of Health Grants (USA) RO1 GM36823 and RO1 HL125076, and Cystic Fibrosis Foundation Grants $12 \mathrm{PO}$ and 13PO (D.J.N.).

\section{Disclosure Statement}

L.M. and H.G. are cofounders of ManRos Therapeutics, L.M. is coinventor in the roscovitine patent, and L.M. and F.B. are coinventors in the 'roscovitine and CF' patent.

\section{References}

1 Lovewell RR, Patankar YR, Berwin B: Mechanisms of phagocytosis and host clearance of Pseudomonas aeruginosa. Am J Physiol Lung Cell Mol Physiol 2014;306:L591-L603.

-2 Gaspar MC, Couet W, Olivier JC, Pais AA, Sousa JJ: Pseudomonas aeruginosa infection in cystic fibrosis lung disease and new perspectives of treatment: a review. Eur J Clin Microbiol Infect Dis 2013;32:1231-1252.

-3 Chmiel JF, Aksamit TR, Chotirmall SH, Dasenbrook EC, Elborn JS, LiPuma JJ, Ranganathan SC, Waters VJ, Ratjen FA: Antibiotic management of lung infections in cystic fibrosis. I. The microbiome, methicillin-resistant Staphylococcus aureus, Gram-negative bacteria, and multiple infections. Ann Am Thorac Soc 2014;11:1298-1306.

$\checkmark 4$ Savoia D: New perspectives in the management of Pseudomonas aeruginosa infections. Future Microbiol 2014;9:917-928.

$\checkmark 5$ Das RR, Kabra SK, Singh M: Treatment of Pseudomonas and Staphylococcus bronchopulmonary infection in patients with cystic fibrosis. ScientificWorldJournal 2013;2013: 645653.

$\checkmark 6$ Borowitz D: CFTR, bicarbonate, and the pathophysiology of cystic fibrosis. Pediatr Pulmonol 2015;50:S4-S30.

7 Caverly LJ, Zhao J, LiPuma JJ: Cystic fibrosis lung microbiome: opportunities to reconsider management of airway infection. Pediatr Pulmonol 2015;50:S31-S38.

$\checkmark 8$ Rieber N, Hector A, Carevic M, Hartl D: Current concepts of immune dysregulation in cystic fibrosis. Int J Biochem Cell Biol 2014; 52:108-112.

9 Witko-Sarsat V: Neutrophils in the innate immunity conundrum of cystic fibrosis: a CFTRrelated matter? J Innate Immun 2013;5:195196.

-10 Hartl D, Gaggar A, Bruscia E, Hector A, Mar$\cos$ V, Jung A, Greene C, McElvaney G, Mall M, Döring G: Innate immunity in cystic fibrosis lung disease. J Cyst Fibros 2012;11:363382 .

11 Stoltz DA, Meyerholz DK, Welsh MJ: Origins of cystic fibrosis lung disease. N Engl J Med 2015;372:1574-1575.

-12 Byrne AJ, Mathie SA, Gregory LG, Lloyd CM Pulmonary macrophages: key players in the innate defence of the airways. Thorax 2015; 70:1189-1196.
3 Nichols DP, Chmiel JF: Inflammation and its genesis in cystic fibrosis. Pediatr Pulmonol 2015;50:S39-S56.

14 MacKenzie T, Gifford AH, Sabadosa KA, Quinton HB, Knapp EA, Goss CH, Marshall BC: Longevity of patients with cystic fibrosis in 2000 to 2010 and beyond: survival analysis of the cystic fibrosis foundation patient registry. Ann Intern Med 2014;161:233-241.

15 Hanrahan JW, Sampson HM, Thomas DY: Novel pharmacological strategies to treat cystic fibrosis. Trends Pharmacol Sci 2013;34: 119-125.

16 O’Neil DA, Fraser-Pitt D: Progress towards next-generation therapeutics for cystic fibrosis. Future Med Chem 2014;6:1067-1079.

17 Bell SC, De Boeck K, Amaral MD: New pharmacological approaches for cystic fibrosis: promises, progress, pitfalls. Pharmacol Ther 2015;145:19-34.

18 Trescott L, Holcomb J, Spellmon N, Mcleod C, Aljehane L, Sun F, Li C, Yang Z: Targeting the root cause of cystic fibrosis. Curr Drug Targets 2015;16:933-944.

19 Amin R, Ratjen F: Emerging drugs for cystic fibrosis. Expert Opin Emerg Drugs 2014;19: 143-155.

20 Cutting GR: Cystic fibrosis genetics: from molecular understanding to clinical application. Nat Rev Genet 2015;16:45-56.

21 Yang H, Ma T: F508del-cystic fibrosis transmembrane regulator correctors for treatment of cystic fibrosis: a patent review. Expert Opin Ther Pat 2015;25:991-1002.

22 Solomon GM, Marshall SG, Ramsey BW, Rowe SM: Breakthrough therapies: cystic fibrosis (CF) potentiators and correctors. Pediatr Pulmonol 2015;50:S3-S13.

23 Goralski JL, Davis SD: Improving complex medical care while awaiting next-generation CFTR potentiators and correctors: the current pipeline of therapeutics. Pediatr Pulmonol 2015;50:S66-S73.

24 Meijer L, Borgne A, Mulner O, Chong JPJ, Blow JJ, Inagaki $\mathrm{N}$, Inagaki $\mathrm{M}$, Delcros JG, Moulinoux JP: Biochemical and cellular effects of roscovitine, a potent and selective inhibitor of the cyclin-dependent kinases cdc2, cdk2 and cdk5. Eur J Biochem 1997;243:527536.
25 Azevedo WF, Leclerc S, Meijer L, Havlicek L, Strnad M, Kim SH: Inhibition of cyclin-dependent kinases by purine analogues: crystal structure of human cdk2 complexed with roscovitine. Eur J Biochem 1997;243:518526.

26 Meijer L, Raymond E: Roscovitine and other purines as kinase inhibitors. From starfish oocytes to clinical trials. Acc Chem Res 2003;36: 417-425

27 Meijer L, Bettayeb K, Galons H: Roscovitine (CYC202, seliciclib); in Yue E, Smith PJ (eds): Monographs on Enzyme Inhibitors. Boca Raton, CRC Press, Taylor \& Francis, 2006, vol 2: CDK Inhibitors and Their Potential as AntiTumor Agents, pp 187-226.

28 Aldoss IT, Tashi T, Ganti AK: Seliciclib in malignancies. Expert Opin Investig Drugs 2009; 18:1957-1965.

29 Knockaert M, Greengard P, Meijer L: Pharmacological inhibitors of cyclin-dependent kinases. Trends Pharmacol Sci 2002;23:417-425.

-30 Malumbres M, Harlow E, Hunt T, Hunter T, Lahti JM, Manning G, Morgan DO, Tsai LH, Wolgemuth DJ: Cyclin-dependent kinases: a family portrait. Nat Cell Biol 2009;11:12751276.

31 Lim S, Kaldis P: Cdks, cyclins and CKIs: roles beyond cell cycle regulation. Development 2013;140:3079-3093.

32 Bach S, Knockaert M, Lozach O, Reinhardt J, Baratte B, Schmitt S, Coburn SP, Tang L, Jiang T, Liang DC, Galons H, Dierick JF, Totzke F, Schächtele C, Lerman AS, Carnero A, Wan Y, Gray N, Meijer L: Roscovitine targets: protein kinases and pyridoxal kinase. J Biol Chem 2005;280:31208-31219.

-33 Tang L, Li MH, Cao P, Wang F, Chang WR, Bach S, Reinhardt J, Koken M, Galons H, Wan Y, Gray N, Meijer L, Jiang T, Liang DC: Crystal structure of pyridoxal kinase in complex with roscovitine and derivatives. J Biol Chem 2005;280:31220-31229.

34 Delehouzé C, Gödl K, Loaëc N, Bruyère C, Desban N, Oumata N, Galons H, Roumeliotis TI, Giannopoulou EG, Grenet J, Twitchell D, Lahti J, Mouchet N, Galibert MD, Garbis S, Meijer L: CDK/CK1 inhibitors roscovitine and CR8 down-regulate amplified MYCN in neuroblastoma cells. Oncogene 2014;33: 5675-5687. 
35 Mapelli M, Massimiliano L, Crovace C, Seeliger M, Tsai LH, Meijer L, Musacchio A: Mechanism of $\mathrm{CDK} 5 / \mathrm{p} 25$ binding by $\mathrm{CDK}$ inhibitors. J Med Chem 2005;48:671-679.

- 36 Bettayeb K, Baunbæk D, Delehouzé C, Loaëc N, Hole A, Baumli S, Endicott JA, Douc-Rasy S, Bénard J, Oumata N, Galons H, Meijer L: CDK inhibitors roscovitine and CR8 trigger Mcl-1 down-regulation and apoptotic cell death in neuroblastoma cells. Genes Cancer 2010;1:369-380.

37 Meijer L, Legraverend M, Bisagni E, Strnad M: Nouveaux dérivés de purine possédant notamment des propriétés anti-prolifératives et leurs applications biologiques. France 9514237; WO 97/20842; EP 0874847; JP 501408; US 2002/0049218 A1; US 10/973 941.

38 Timsit S, Meen B, Meijer L: Utilisation de la S-roscovitine pour la fabrication d'un médicament. 06/02773, March 30, 2006.

39 Becq F, Meijer L: Utilisations de dérivés de purines pour la fabrication de médicaments pour le traitement de la mucoviscidose et de maladies liées à un défaut d'adressage des protéines dans les cellules. FR 0410958, filed October 15, 2004; WO2006/042949; EP1802310; CA2584195; US 2007275986.

-40 Oumata N, Ferandin Y, Meijer L, Galons H: Practical synthesis of roscovitine and CR8. Org Process Res Dev 2009;13:641-644.

-41 Menn B, Bach B, Blevins TL, Campbell M, Ivanov A, Ben-Ari Y, Meijer L, Timsit S: Delayed treatment with systemic (S)-roscovitine provides CDK5-mediated neuroprotection in animal stroke models. PLoS One 2010; 5:e12117.

42 Chagniel L, Robitaille C, Lebel M, Cyr M: Striatal inhibition of calpains prevents levodopainduced neurochemical changes and abnormal involuntary movements in the hemiparkinsonian rat model. Neurobiol Dis 2012;45: 645-655.

43 Kabadi SV, Stoica BA, Byrnes KR, Hanscom M, Loane DJ, Faden AI: Selective CDK inhibitor limits neuroinflammation and progressive neurodegeneration after brain trauma. J Cereb Blood Flow Metab 2012;32:137-149.

-44 Schang LM, Bantly A, Knockaert M, Shaheen F, Meijer L, Malim MH, Gray NS, Schaffer PA: Pharmacological cyclin-dependent kinase inhibitors inhibit replication of wildtype and drug-resistant strains of herpes simplex virus and human immunodeficiency virus type 1 by targeting cellular, not viral, proteins. J Virol 2002;76:7874-7882.

-45 Bukanov NO, Smith LA, Klinger KW, Ledbetter SR, Ibraghimov-Beskrovnaya O: Longlasting arrest of murine polycystic kidney disease with CDK inhibitor roscovitine. Nature 2006;444:949-952.

-46 Bukanov NO, Moreno SE, Natoli TA, Rogers KA, Smith LA, Ledbetter SR, Oumata N, Galons H, Meijer L, Ibraghimov-Beskrovnaya $\mathrm{O}$ : CDK inhibitors R-roscovitine and S-CR8 effectively block renal and hepatic cystogenesis in an orthologous model of ADPKD. Cell Cycle 2012;11:4040-4046.
47 Pippin JW, Qu Q, Meijer L, Shankland SJ: Direct in vivo inhibition of the nuclear cell cycle cascade in experimental mesangial proliferative glomerulonephritis with roscovitine, a novel cyclin-dependent kinase antagonist. J Clin Invest 1997;100:2512-2520.

48 Gherardi D, D’Agati V, Chu TH, Barnett A, Gianella-Borradori A, Gelman IH, Nelson PJ: Reversal of collapsing glomerulopathy in mice with the cyclin-dependent kinase inhibitor CYC202. J Am Soc Nephrol 2004;15: 1212-1222.

49 Milovanceva-Popovska M, Kunter U, Ostendorf T, Petermann A, Rong S, Eitner F, Kerjaschki D, Barnett A, Floege J: R-Roscovitine (CYC202) alleviates renal cell proliferation in nephritis without aggravating podocyte injury. Kidney Int 2005;67:1362-1370.

50 Zoja C, Casiraghi F, Conti S, Corna D, Rottoli D, Cavinato RA, Remuzzi G, Benigni A: Cyclin-dependent kinase inhibition limits glomerulonephritis and extends lifespan of mice with systemic lupus. Arthritis Rheum 2007; 56:1629-1637.

51 Safety and intraocular pressure (IOP)-lowering efficacy of AL-39256 in patients with openangle glaucoma or ocular hypertension. https:// clinicaltrialsgov/ct2/show/NCT00761709.

52 Cholkar K, Trinh HM, Pal D, Mitra AK: Discovery of novel inhibitors for the treatment of glaucoma. Expert Opin Drug Discov 2015; 10 : 293-313.

53 Liang M, Tarr TB, Bravo-Altamirano K, Valdomir G, Rensch G, Swanson L, DeStefino NR, Mazzarisi CM, Olszewski RA, Wilson GM, Meriney SD, Wipf P: Synthesis and biological evaluation of a selective $\mathrm{N}$ - and P/Qtype calcium channel agonist. ACS Med Chem Lett 2012;3:985-990.

54 Tarr TB, Valdomir G, Liang M, Wipf P, Meriney SD: New calcium channel agonists as potential therapeutics in Lambert-Eaton myasthenic syndrome and other neuromuscular diseases. Ann NY Acad Sci 2012;1275:85-91.

55 Wen H, Linhoff MW, Hubbard JM, Nelson NR, Stensland D, Dallman J, Mandel G, Brehm P: Zebrafish calls for reinterpretation for the roles of $\mathrm{P} / \mathrm{Q}$ calcium channels in neuromuscular transmission. J Neurosci 2013;33: 7384-7392.

56 Malgrange B, Knockaert M, Belachew S, Nguyen L, Moonen G, Meijer L, Lefebvre PP: The inhibition of cyclin-dependent kinases induces differentiation of supernumerary hair cells and Deiters' cells in the developing organ of Corti. FASEB J 2003;17:2136-2138.

57 Yarotskyy V, Gao G, Peterson BZ, Elmslie KS: The Timothy syndrome mutation of cardiac CaV12 (L-type) channels: multiple altered gating mechanisms and pharmacological restoration of inactivation. J Physiol 2009;587: 551-565.

58 Yazawa M, Hsueh B, Jia X, Pasca AM, Bernstein JA, Hallmayer J, Dolmetsch RE: Using induced pluripotent stem cells to investigate cardiac phenotypes in Timothy syndrome. Nature 2011;471:230-234.
59 Paşca SP, Portmann T, Voineagu I, Yazawa M, Shcheglovitov A, Paşca AM, Cord B, Palmer TD, Chikahisa S, Nishino S, Bernstein JA, Hallmayer J, Geschwind DH, Dolmetsch RE: Using iPSC-derived neurons to uncover cellular phenotypes associated with Timothy syndrome. Nat Med 2011;17:1657-1662.

60 Steinman RA, Robinson AR, Feghali-Bostwick CA: Antifibrotic effects of roscovitine in normal and scleroderma fibroblasts. PLoS One 2012;7:e48560.

61 Liu NA, Jiang H, Ben-Shlomo A, Wawrowsky K, Fan XM, Lin S, Melmed S: Targeting zebrafish and murine pituitary corticotroph tumors with a cyclin-dependent kinase (CDK) inhibitor. Proc Natl Acad Sci USA 2011;108: 8414-8419.

-62 Liu NA, Araki T, Cuevas-Ramos D, Hong J, Ben-Shlomo A, Tone Y, Tone M, Melmed S: Cyclin E-mediated human proopiomelanocortin regulation as a therapeutic target for Cushing disease. J Clin Endocrinol Metab 2015;100:2557-2564

63 Kitani K, Oguma S, Nishiki TI, Ohmori I, Galons H, Matsui H, Meijer L, Tomizawa K: A Cdk5 inhibitor enhances the induction of insulin secretion by exendin- 4 both in vitro and in vivo. J Physiol Sci 2007;57:235-239.

64 Benson C, White J, De Bono J, O’Donnell A, Raynaud F, Cruickshank C, McGrath H, Walton M, Workman P, Kaye S, Cassidy J, Gianella-Borradori A, Judson I, Twelves C: A phase I trial of the selective oral cyclin-dependent kinase inhibitor seliciclib (CYC202; R-roscovitine), administered twice daily for 7 days every 21 days. Br J Cancer 2007;96:29-37.

65 Le Tourneau C, Faivre S, Laurence V, Delbaldo C, Vera K, Girre V, Chiao J, Armour S, Frame S, Green SR, Gianella-Borradori A, Diéras V, Raymond E: Phase I evaluation of seliciclib (R-roscovitine), a novel oral cyclindependent kinase inhibitor, in patients with advanced malignancies. Eur J Cancer 2010; 46:3243-3250

66 de la Motte S, Gianella-Borradori A: Pharmacokinetic model of R-roscovitine and its metabolite in healthy male subjects. Int J Clin Pharmacol Ther 2004;42:232-239.

67 Hsieh WS, Soo R, Peh BK, Loh T, Dong D, Soh D, Wong LS, Green S, Chiao J, Cui CY, Lai YF, Lee SC, Mow B, Soong R, Salto-Tellez M, Goh BC: Pharmacodynamic effects of seliciclib, an orally administered cell cycle modulator, in undifferentiated nasopharyngeal cancer. Clin Cancer Res 2009;15:1435-1442.

68 Seliciclib (CYC202). http://www.cyclacel.com/ research_programs_oncology_cyc202.shtml.

69 Treatment of Cushing's disease with R-roscovitine. https://clinicaltrials.gov/ct2/show/NC T02160730? term $=$ NCT02160730\&rank $=1$.

70 ISRCTNregistry. http://www.isrctn.com/ ISRCTN06857980.

71 Gibbons J, Arat S, Rzucidlo J, Miyoshi K, Waltenburg R, Respess D, Venable A, Stice S: Enhanced survivability of cloned calves derived from roscovitine-treated adult somatic cells. Biol Reprod 2002;66:895-900. 
72 Hinrichs K, Choi YH, Varner DD, Hartman DL: Production of cloned horse foals using roscovitine-treated donor cells and activation with sperm extract and/or ionomycin. Reproduction 2007;134:319-325.

73 Vita M, Abdel-Rehim M, Olofsson S, Hassan Z, Meurling L, Sidén A, Sidén M, Pettersson T, Hassan M: Tissue distribution, pharmacokinetics and identification of roscovitine metabolites in rat. Eur J Pharm Sci 2005;25:91-103.

74 Rossi AG, Sawatzky DA, Walker A, Ward C, Sheldrake TA, Riley NA, Caldicott A, Martinez-Losa M, Walker TR, Duffin R, Gray M, Crescenzi E, Martin MC, Brady HJ, Savill JS, Dransfield I, Haslett C: Cyclin-dependent kinase inhibitors enhance the resolution of inflammation by promoting inflammatory cell apoptosis. Nat Med 2006; 12:1056-1064; erratum 1434.

-75 Hoogendijk AJ, Roelofs JJ, Duitman J, van Lieshout MH, Blok DC, van der Poll T, Wieland CW: R-Roscovitine reduces lung inflammation induced by lipoteichoic acid and Streptococcus pneumoniae. Mol Med 2012;18: 1086-1095.

76 Hoogendijk AJ, Kuipers MT, van der Poll T, Schultz MJ, Wieland CW: Cyclin-dependent kinase inhibition reduces lung damage in a mouse model of ventilator-induced lung injury. Shock 2012;38:375-380.

$\longrightarrow 77$ Nutley BP, Raynaud FI, Wilson SC, Fischer PM, Hayes A, Goddard PM, McClue SJ, Jarman M, Lane DP, Workman P: Metabolism and pharmacokinetics of the cyclin-dependent kinase inhibitor R-roscovitine in the mouse. Mol Cancer Ther 2005;4:125-139.

-78 Norez C, Vandebrouck C, Noel S, Durieu E, Oumata N, Galons H, Antigny F, Chatelier A, Bois P, Meijer L, Becq F: Roscovitine is a proteostasis regulator rescuing the trafficking defect of F508del-CFTR by a cyclin-dependent kinase (CDK) independent mechanism of action. Br J Pharmacol 2014;171:4831-4849.

-79 Riazanski V, Gabdoulkhakova AG, Boynton LS, Eguchi RR, Deriy LV, Hogarth DK, Loaëc $\mathrm{N}$, Oumata $\mathrm{N}$, Galons $\mathrm{H}$, Brown ME, Shevchenko P, Gallan AJ, Yoo SG, Naren AP, Villereal ML, Beacham DW, Bindokas VP, Birnbaumer L, Meijer L, Nelson DJ: TRPC6 channel translocation into phagosomal membrane augments phagosomal function. Proc Natl Acad Sci USA 2015;112:E6486-E6495.

-80 Trzcinska-Daneluti AM, Nguyen L, Jiang C, Fladd C, Uehling D, Prakesch M, Al-awar R, Rotin D: Use of kinase inhibitors to correct $\triangle$ F508-CFTR function. Mol Cell Proteomics 2012;11:745-757.

81 Tolle N, Kunick C: Paullones as inhibitors of protein kinases. Curr Top Med Chem 2011; 11:1320-1332.

\$2 Di A, Brown ME, Deriy LV, Li C, Szeto FL, Chen Y, Huang P, Tong J, Naren AP, Bindokas V, Palfrey HC, Nelson DJ: CFTR regulates phagosome acidification in macrophages and alters bactericidal activity. Nat Cell Biol 2006; 8:933-944.
83 Del Porto P, Cifani N, Guarnieri S, Di Domenico EG, Mariggiò MA, Spadaro F, Guglietta S, Anile M, Venuta F, Quattrucci S, Ascenzioni F: Dysfunctional CFTR alters the bactericidal activity of human macrophages against Pseudomonas aeruginosa. PLoS One 2011;6:e19970.

84 Barasch J, Kiss B, Prince A, Saiman L, Gruenert $D$, al-Awqati Q: Defective acidification of intracellular organelles in cystic fibrosis. $\mathrm{Na}$ ture 1991;352:70-73.

85 Teichgräber V, Ulrich M, Endlich N, Riethmüller J, Wilker B, De Oliveira-Munding CC, van Heeckeren AM, Barr ML, von Kürthy G, Schmid KW, Weller M, Tümmler B, Lang F, Grassme H, Döring G, Gulbins E: Ceramide accumulation mediates inflammation, cell death and infection susceptibility in cystic fibrosis. Nat Med 2008;14:382-391.

86 Deriy LV, Gomez EA, Zhang G, Beacham DW, Hopson JA, Gallan AJ, Shevchenko PD, Bindokas VP, Nelson DJ: Disease-causing mutations in the cystic fibrosis transmembrane conductance regulator determine the functional responses of alveolar macrophages. J Biol Chem 2009;284:35926-35938.

87 Lamothe J, Valvano MA: Burkholderia cenocepacia-induced delay of acidification and phagolysosomal fusion in cystic fibrosis transmembrane conductance regulator (CFTR)-defective macrophages. Microbiology $2008 ; 154: 3825-3834$.

88 Zhang Y, Li X, Grassme H, Doring G, Gulbins E: Alterations in ceramide concentration and $\mathrm{pH}$ determine the release of reactive oxygen species by Cftr-deficient macrophages on infection. J Immunol 2010;184:5104-5111.

89 Bonfield TL, Hodges CA, Cotton CU, Drumm ML: Absence of the cystic fibrosis transmembrane regulator (CFTR) from myeloid-derived cells slows resolution of inflammation and infection. J Leukoc Biol 2012;92:11111122 .

90 Machen TE: Innate immune response in CF airway epithelia: hyperinflammatory? Am J Physiol 2006;291:C218-C230.

91 Haggie PM, Verkman AS: Cystic fibrosis transmembrane conductance regulator-independent phagosomal acidification in macrophages. J Biol Chem 2007;282:31422-31428.

92 Haggie PM, Verkman AS: Unimpaired lysosomal acidification in respiratory epithelial cells in cystic fibrosis. J Biol Chem 2008;284. 7681-7686.

93 Barriere H, Bagdany M, Bossard F, Okiyoneda T, Wojewodka G, Gruenert D, Radzioch D, Lukacs GL: Revisiting the role of cystic fibrosis transmembrane conductance regulator and counterion permeability in the $\mathrm{pH}$ regulation of endocytic organelles. Mol Biol Cell 2009;20:3125-3141.

94 Steinberg BE, Huynh KK, Brodovitch A, Jabs S, Stauber T, Jentsch TJ, Grinstein S: A cation counterflux supports lysosomal acidification. J Cell Biol 2010;189:1171-1186.
-95 Rogers CS, Stoltz DA, Meyerholz DK, Ostedgaard LS, Rokhlina T, Taft PJ, Rogan MP, Pezzulo AA, Karp PH, Itani OA, Kabel AC, Wohlford-Lenane CL, Davis GJ, Hanfland RA, Smith TL, Samuel M, Wax D, Murphy CN, Rieke A, Whitworth K, Uc A, Starner TD, Brogden KA, Shilyansky J, McCray PB Jr, Zabner J, Prather RS, Welsh MJ: Disruption of the CFTR gene produces a model of cystic fibrosis in newborn pigs. Science 2008; 321:1837-1841.

$\$ 96$ Rogers CS, Abraham WM, Brogden KA, Engelhardt JF, Fisher JT, McCray PB Jr, McLennan G, Meyerholz DK, Namati E, Ostedgaard LS, Prather RS, Sabater JR, Stoltz DA, Zabner J, Welsh MJ: The porcine lung as a potential model for cystic fibrosis. Am J Physiol Lung Cell Mol Physiol 2008; 295:L240-L263.

-97 Rogers CS, Hao Y, Rokhlina T, Samuel M, Stoltz DA, Li Y, Petroff E, Vermeer DW, Kabel AC, Yan Z, Spate L, Wax D, Murphy CN, Rieke A, Whitworth K, Linville ML, Korte SW, Engelhardt JF, Welsh MJ, Prather RS: Production of CFTR-null and CFTR- $\triangle \mathrm{F} 508$ heterozygous pigs by adeno-associated virus-mediated gene targeting and somatic cell nuclear transfer. J Clin Invest 2008;118 1571-1577.

98 Wine JJ: The development of lung disease in cystic fibrosis pigs. Sci Transl Med 2010;2: $29 \mathrm{ps} 20$.

99 Moreland JG, Davis AP, Bailey G, Nauseef WM, Lamb FS: Anion channels, including ClC-3, are required for normal neutrophil oxidative function, phagocytosis, and transendothelial migration. J Biol Chem 2006; 281:12277-12288

100 Painter RG, Valentine VG, Lanson NA Jr, Leidal K, Zhang Q, Lombard G, Thompson C, Viswanathan A, Nauseef WM, Wang G, Wang G: CFTR expression in human neutrophils and the phagolysosomal chlorination defect in cystic fibrosis. Biochemistry 2006;45:10260-10269.

101 Painter RG, Marrero L, Lombard GA, Valentine VG, Nauseef WM, Wang G: CFTRmediated halide transport in phagosomes of human neutrophils. J Leukoc Biol 2010;87: 933-942.

102 Painter RG, Bonvillain RW, Valentine VG, Lombard GA, LaPlace SG, Nauseef WM, Wang G: The role of chloride anion and CFTR in killing of Pseudomonas aeruginosa by normal and CF neutrophils. J Leukoc Biol 2008;83:1345-1353.

103 Preti D, Szallasi A, Patacchini R: TRP channels as therapeutic targets in airway disorders: a patent review. Expert Opin Ther Pat 2012;22:663-695.

104 Banner KH, Igney F, Poll C: TRP channels emerging targets for respiratory disease. Pharmacol Ther 2011;130:371-384.

105 Abbott-Banner K, Poll C, Verkuyl JM: Targeting TRP channels in airway disorders. Curr Top Med Chem 2013;13:310-321. 
106 Nilius B, Szallasi A: Transient receptor potential channels as drug targets: from the science of basic research to the art of medicine. Pharmacol Rev 2014;66:676-814.

107 Ong HL, de Souza LB, Cheng KT, Ambudkar IS: Physiological functions and regulation of TRPC channels. Handb Exp Pharmacol 2014;223:1005-1034.

108 Holzer P, Izzo AA: The pharmacology of TRP channels. Br J Pharmacol 2014;171: 2469-2473.

109 Heiner I, Eisfeld J, Halaszovich CR, Wehage E, Jüngling E, Zitt C, Lückhoff A: Expression profile of the transient receptor potential (TRP) family in neutrophil granulocytes: evidence for currents through long TRP channel 2 induced by ADP-ribose and NAD. Biochem J 2003;371:1045-1053.

110 Heiner I, Eisfeld J, Lückhoff A: Role and regulation of TRP channels in neutrophil granulocytes. Cell Calcium 2003;33:533-540.

-111 McMeekin SR, Dransfield I, Rossi AG, Haslett C, Walker TR: E-selectin permits communication between PAF receptors and TRPC channels in human neutrophils. Blood 2006; 107:4938-4945.

-112 Damann N, Owsianik G, Li S, Poll C, Nilius $\mathrm{B}$ : The calcium-conducting ion channel transient receptor potential canonical 6 is involved in macrophage inflammatory protein-2-induced migration of mouse neutrophils. Acta Physiol (Oxf) 2009;195:3-11.

$\checkmark 113$ Finney-Hayward TK, Popa MO, Bahra P, Li S, Poll CT, Gosling M, Nicholson AG, Russell RE, Kon OM, Jarai G, Westwick J, Barnes PJ, Donnelly LE: Expression of transient receptor potential C6 channels in human lung macrophages. Am J Respir Cell Mol Biol 2010;43:296-304.

114 Weissmann N, Sydykov A, Kalwa H, Storch U, Fuchs B, Mederos y Schnitzler M, Brandes RP, Grimminger F, Meissner M, Freichel M, Offermanns S, Veit F, Pak O, Krause KH, Schermuly RT, Brewer AC, Schmidt HH, Seeger W, Shah AM, Gudermann T, Ghofrani HA, Dietrich A: Activation of TRPC6 channels is essential for lung ischaemiareperfusion induced oedema in mice. Nat Commun 2012;3:649-658.

-115 Sel S, Rost BR, Yildirim AO, Sel B, Kalwa H, Fehrenbach H, Renz H, Gudermann T, Dietrich A: Loss of classical transient receptor potential 6 channel reduces allergic airway response. Clin Exp Allergy 2008;38:1548-1558.

116 Harteneck C, Gollasch M: Pharmacological modulation of diacylglycerol-sensitive TRPC3/6/7 channels. Curr Pharm Biotechnol 2011;12:35-41.

-117 Leuner K, Kazanski V, Müller M, Essin K, Henke B, Gollasch M, Harteneck C, Müller WE: Hyperforin - a key constituent of St John's wort specifically activates TRPC6 channels. FASEB J 2007;21:4101-4111.

118 Miehe S, Kleemann H-W, Struebing C: Use of Norgestimate as a selective inhibitor of TRPC3, TRPC6 and TRPC7 ion channels. EP 2266575 A3; October 26, 2007.
119 Antigny F, Norez C, Dannhoffer L, Bertrand J, Raveau D, Corbi P, Jayle C, Becq F, Vandebrouck C: Transient receptor potential canonical channel 6 links $\mathrm{Ca}^{2+}$ mishandling to cystic fibrosis transmembrane conductance regulator channel dysfunction in cystic fibrosis. Am J Respir Cell Mol Biol 2011;44: 83-90.

120 Antigny F, Norez C, Becq F, Vandebrouck C: CFTR and $\mathrm{Ca}$ signaling in cystic fibrosis. Front Pharmacol 2011;2:67.

121 Hayes E, Pohl K, McElvaney NG, Reeves EP: The cystic fibrosis neutrophil: a specialized yet potentially defective cell. Arch Immunol Ther Exp (Warsz) 2011;59:97-112.

122 Van de Weert-van Leeuwen PB, Van Meegen MA, Speirs JJ, Pals DJ, Rooijakkers SH, Van der Ent CK, Terheggen-Lagro SW, Arets HG, Beekman JM: Optimal complement-mediated phagocytosis of Pseudomonas aeruginosa by monocytes is cystic fibrosis transmembrane conductance regulatordependent. Am J Respir Cell Mol Biol 2013; 49:463-470.

123 Zhou Y, Song K, Painter RG, Aiken M, Reiser J, Stanton BA, Nauseef WM, Wang G: Cystic fibrosis transmembrane conductance regulator recruitment to phagosomes in neutrophils. J Innate Immun 2013;5:219230.

124 Pohl K, Hayes E, Keenan J, Henry M, Meleady P, Molloy K, Jundi B, Bergin DA, McCarthy C, McElvaney OJ, White MM, Clynes M, Reeves EP, McElvaney NG: A neutrophil intrinsic impairment affecting Rab27a and degranulation in cystic fibrosis is corrected by CFTR potentiator therapy. Blood 2014;124:999-1009.

-125 Ng HP, Zhou Y, Song K, Hodges CA, Drumm ML, Wang G: Neutrophil-mediated phagocytic host defense defect in myeloid CFTR-inactivated mice. PLoS One 2014; 9:e106813.

126 Garcia-Romo GS, Caielli S, Vega B, Connolly J, Allantaz F, Xu Z, Punaro M, Baisch J, Guiducci C, Coffman RL, Barrat FJ, Banchereau J, Pascual V: Netting neutrophils are major inducers of type I IFN production in pediatric systemic lupus erythematosus. Sci Transl Med 2011;3:73ra20.

-127 Khandpur R, Carmona-Rivera C, Vivekanandan-Giri A, Gizinski A, Yalavarthi S, Knight JS, Friday S, Li S, Patel RM, Subramanian V, Thompson P, Chen P, Fox DA, Pennathur S, Kaplan MJ: NETs are a source of citrullinated autoantigens and stimulate inflammatory responses in rheumatoid arthritis. Sci Transl Med 2013;5:178ra40.

128 Dwyer M, Shan Q, D’Ortona S, Maurer R, Mitchell R, Olesen H, Thiel S, Huebner J, Gadjeva M: Cystic fibrosis sputum DNA has NETosis characteristics and neutrophil extracellular trap release is regulated by macrophage migration-inhibitory factor. J Innate Immun 2014;6:765-779.

-129 Manzenreiter R, Kienberger F, Marcos V, Schilcher K, Krautgartner WD, Obermayer
A, Huml M, Stoiber W, Hector A, Griese M, Hannig M, Studnicka M, Vitkov L, Hartl D: Ultrastructural characterization of cystic fibrosis sputum using atomic force and scanning electron microscopy. J Cyst Fibros 2011;11:84-92.

130 Papayannopoulos V, Staab D, Zychlinsky A: Neutrophil elastase enhances sputum solubilization in cystic fibrosis patients receiving DNase therapy. PLoS One 2011; 6:e28526.

131 Young RL, Malcolm KC, Kret JE, Caceres SM, Poch KR, Nichols DP, Taylor-Cousar JL, Saavedra MT, Randell SH, Vasil ML, Burns JL, Moskowitz SM, Nick JA: Neutrophil extracellular trap (NET)-mediated killing of Pseudomonas aeruginosa: evidence of acquired resistance within the CF airway, independent of CFTR. PLoS One 2011;6:e23637.

132 Yoo DG, Winn M, Pang L, Moskowitz SM, Malech HL, Leto TL, Rada B: Release of cystic fibrosis airway inflammatory markers from Pseudomonas aeruginosa-stimulated human neutrophils involves NADPH oxidase-dependent extracellular DNA trap formation. J Immunol 2010;192:4728-4738.

133 Dubois AV, Gauthier A, Brea D, Varaigne F, Diot P, Gauthier F, Attucci S: Influence of DNA on the activities and inhibition of neutrophil serine proteases in cystic fibrosis sputum. Am J Respir Cell Mol Biol 2012;47: 80-86.

134 Yoo D, Floyd M, Winn M, Moskowitz SM, Rada B: NET formation induced by Pseudomonas aeruginosa cystic fibrosis isolates measured as release of myeloperoxidaseDNA and neutrophil elastase-DNA complexes. Immunol Lett 2014;160:186-194.

135 Metzler KD, Fuchs TA, Nauseef WM, Reumaux D, Roesler J, Schulze I, Wahn V, Papayannopoulos V, Zychlinsky A: Myeloperoxidase is required for neutrophil extracellular trap formation: implications for innate immunity. Blood 2011;117:953-959.

136 Papayannopoulos V, Metzler KD, Hakkim A, Zychlinsky A: Neutrophil elastase and myeloperoxidase regulate the formation of neutrophil extracellular traps. J Cell Biol 2010;191:677-691.

-137 Sørensen OE, Clemmensen SN, Dahl SL, Østergaard O, Heegaard NH, Glenthøj A, Nielsen FC, Borregaard N: Papillon-Lefèvre syndrome patient reveals species-dependent requirements for neutrophil defenses. J Clin Invest 2014;124:4539-4548.

-138 Wang Y, Li M, Stadler S, Correll S, Li P, Wang D, Hayama R, Leonelli L, Han $\mathrm{H}$, Grigoryev SA, Allis CD, Coonrod SA: Histone hypercitrullination mediates chromatin decondensation and neutrophil extracellular trap formation. J Cell Biol 2009;184: 205-213.

139 Fuchs TA, Abed U, Goosmann C, Hurwitz R, Schulze I, Wahn V, Weinrauch Y, Brinkmann V, Zychlinsky A: Novel cell death program leads to neutrophil extracellular traps. J Cell Biol 2007;176:231-241. 
140 Mitroulis I, Kambas K, Chrysanthopoulou A, Skendros P, Apostolidou E, Kourtzelis I, Drosos GI, Boumpas DT, Ritis K: Neutrophil extracellular trap formation is associated with IL-1 $\beta$ and autophagy-related signaling in gout. PLoS One 2011;6:e29318.

141 Itakura A, McCarty OJT: Pivotal role for the mTOR pathway in the formation of neutrophil extracellular traps via regulation of autophagy. Am J Physiol Cell Physiol 2013; 305:C348-C354.

142 Leffler J, Martin M, Gullstrand B, Tydén H, Lood C, Truedsson L, Bengtsson AA, Blom AM: Neutrophil extracellular traps that are not degraded in systemic lupus erythematosus activate complement exacerbating the disease. J Immunol 2012;188:3522-3531.

143 Cohen TS, Prince A: Cystic fibrosis: a mucosal immunodeficiency syndrome. Nat Med 2012;18:509-519.

144 Dhooghe B, Noël S, Huaux F, Leal T: Lung inflammation in cystic fibrosis: pathogenesis and novel therapies. Clin Biochem 2014;47: 539-546.

145 Banner KH, De Jonge H, Elborn S, Growcott E, Gulbins E, Konstan M, Moss R, Poll C, Randell SH, Rossi AG, Thomas L, Waltz D: Highlights of a workshop to discuss targeting inflammation in cystic fibrosis. J Cyst Fibros 2009;8:1-8.

146 Cantin AM, Hartl D, Konstan MW, Chmiel JF: Inflammation in cystic fibrosis lung disease: pathogenesis and therapy. J Cyst Fibros 2015;14:419-430.

147 Gray RD, McCullagh BN, McCray PB: NETs and CF lung disease: current status and future prospects. Antibiotics 2015;4:62-75.

148 Rahman S, Gadjeva M: Does NETosis contribute to the bacterial pathoadaptation in cystic fibrosis? Front Immunol 2014;5:378.

149 Jovic S, Shikhagaie M, Mörgelin M, Kjellström S, Erjefalt J, Olin AI, Frick IM, Egesten A: Expression of MIG/CXCL9 in cystic fibrosis and modulation of its activities by elastase of Pseudomonas aeruginosa. J Innate Immun 2014;6:846-859.

150 Leitch AE, Haslett C, Rossi AG: Cyclin-dependent kinase inhibitor drugs as potential novel anti-inflammatory and pro-resolution agents. Br J Pharmacol 2009;158:1004-1016.

151 El Kebir D, Filep JG: Role of neutrophil apoptosis in the resolution of inflammation. ScientificWorldJournal 2010;10:1731-1748.

-152 Leitch AE, Lucas CD, Marwick JA, Duffin R, Haslett C, Rossi AG: Cyclin-dependent kinases 7 and 9 specifically regulate neutrophil transcription and their inhibition drives apoptosis to promote resolution of inflammation. Cell Death Differ 2012;19:19501961.

153 Leitch AE, Riley NA, Sheldrake TA, Festa M, Fox S, Duffin R, Haslett C, Rossi AG: The cyclin-dependent kinase inhibitor R-roscovitine down-regulates $\mathrm{Mcl}-1$ to override pro-inflammatory signalling and drive neutrophil apoptosis. Eur J Immunol 2010;40: 1127-1138.
154 Jackson RC, Radivoyevitch T: Modelling cAbl signalling in activated neutrophils: the anti-inflammatory effect of seliciclib. Biodiscovery 2013;7:4.

155 Bettayeb K, Baunbæk D, Delehouzé C, Loaëc N, Hole A, Baumli S, Endicott JA, Douc-Rasy S, Bénard J, Oumata N, Galons H, Meijer $\mathrm{L}$ : CDK inhibitors roscovitine and CR8 trigger Mcl-1 down-regulation and apoptotic cell death in neuroblastoma cell lines. Genes Cancer 2010;1:369-380.

156 Du J, Wei N, Guan T, Xu H, An J, Pritchard KA Jr, Shi Y: Inhibition of CDKs by roscovitine suppressed LPS-induced NO production through inhibiting $\mathrm{NF \kappa B}$ activation and $\mathrm{BH}_{4}$ biosynthesis in macrophages. Am J Physiol Cell Physiol 2009;297:C742-C749.

157 Jhou RS, Sun KH, Sun GH, Wang HH, Chang CI, Huang HC, Lu SY, Tang SJ: Inhibition of cyclin-dependent kinases by olomoucine and roscovitine reduces lipopolysaccharide-induced inflammatory responses via down-regulation of nuclear factor $\kappa B$. Cell Prolif 2009;42:141-149.

158 Cosimo E, McCaig AM, Carter-Brzezinski LJM, Wheadon H, Leach MT, Lester K, Berthou C, Durieu E, Oumata N, Galons H, Meijer L, Michie AM: Inhibition of NF-kBmediated signaling by the cyclin-dependent kinase inhibitor CR8 overcomes prosurvival stimuli to induce apoptosis in chronic lymphocytic leukemia cells. Clin Cancer Res 2013;19:2393-2405.

159 Loynes CA, Martin JS, Robertson A, Trushell DM, Ingham PW, Whyte MK, Renshaw SA: Pivotal advance: pharmacological manipulation of inflammation resolution during spontaneously resolving tissue neutrophilia in the zebrafish. J Leukoc Biol 2010;87: 203-212.

160 Hall C, Crosier P: Editorial: maintaining the balance - fishing for drugs to treat persistent neutrophilic inflammation. J Leukoc Biol 2010;87:189-191.

161 Koedel U, Frankenberg T, Kirschnek S, Obermaier B, Häcker H, Paul R, Häcker G: Apoptosis is essential for neutrophil functional shutdown and determines tissue damage in experimental pneumococcal meningitis. PLoS Pathog 2009;5:e1000461.

162 Berberich N, Uhl B, Joore J, Schmerwitz UK, Mayer BA, Reichel CA, Krombach F, Zahler S, Vollmar AM, Fürst R: Roscovitine blocks leukocyte extravasation by inhibition of cyclin-dependent kinases 5 and 9. Br J Pharmacol 2011;163:1086-1098.

163 Witko-Sarsat V, Halbwachs-Mecarelli L, Schuster A, Nusbaum P, Ueki I, Canteloup S, Lenoir G, Descamps-Latscha B, Nadel JA: Proteinase 3 , a potent secretagogue in airways, is present in cystic fibrosis sputum. Am J Respir Cell Mol Biol 1999;20:729-736.

164 Witko-Sarsat V, Sermet-Gaudelus I, Lenoir G, Descamps-Latscha B: Inflammation and CFTR: might neutrophils be the key in cystic fibrosis? Mediators Inflamm 1999;8:7-11.
65 Gifford AM, Chalmers JD: The role of neutrophils in cystic fibrosis. Curr Opin Hematol 2014;21:16-22.

166 Downey DG, Bell SC, Elborn JS: Neutrophils in cystic fibrosis. Thorax 2009;64:81-88.

167 Hartl D, Gaggar A, Bruscia E, Hector A, Marcos V, Jung A, Greene C, McElvaney G, Mall M, Döring G: Innate immunity in cystic fibrosis lung disease. J Cyst Fibros 2012;11: 363-382.

168 Witko-Sarsat V: Neutrophils in the innate immunity conundrum of cystic fibrosis: a CFTR-related matter? J Innate Immun 2013; 5:195-196.

169 Moriceau S, Kantari C, Mocek J, Davezac N, Gabillet J, Guerrera IC, Brouillard F, Tondelier D, Sermet-Gaudelus I, Danel C, Lenoir G, Daniel S, Edelman A, Witko-Sarsat V: Coronin-1 is associated with neutrophil survival and is cleaved during apoptosis: potential implication in neutrophils from cystic fibrosis patients. J Immunol 2009;182:7254-7263.

170 McKeon DJ, Condliffe AM, Cowburn AS, Cadwallader KC, Farahi N, Bilton D, Chilvers ER: Prolonged survival of neutrophils from patients with $\triangle$ F508 CFTR mutations. Thorax 2008;63:660-661.

171 Moriceau S, Lenoir G, Witko-Sarsat V: In cystic fibrosis homozygotes and heterozygotes, neutrophil apoptosis is delayed and modulated by diamide or roscovitine: evidence for an innate neutrophil disturbance. J Innate Immun 2010;2:260-266.

172 Gautam S, Kirschnek S, Wiesmeier M, Vier J, Häcker G: Roscovitine-induced apoptosis in neutrophils and neutrophil progenitors is regulated by the Bcl-2-family members Bim, Puma, Noxa and Mcl-1. PLoS One 2013; 8:e79352.

173 Dibbert B, Weber M, Nikolaizik WH, Vogt P, Schöni MH, Blaser K, Simon H-U: Cytokine-mediated Bax deficiency and consequent delayed neutrophil apoptosis: a general mechanism to accumulate effector cells in inflammation. Proc Natl Acad Sci USA 1999;96:13330-13335.

174 Roberts RL, Ank BJ, Stiehm ER: Human eosinophils are more toxic than neutrophils in antibody-independent killing. J Allergy Clin Immunol 1991;87:1105-1115.

175 Koller DY, Götz M, Eichler I, Urbanek R: Eosinophilic activation in cystic fibrosis. Thorax 1994;49:496-499.

176 Maturu VN, Agarwal R: Prevalence of Aspergillus sensitization and allergic bronchopulmonary aspergillosis in cystic fibrosis: systematic review and meta-analysis. Clin Exp Allergy 2015;45:1765-1778.

177 Azzawi M, Johnston PW, Majumdar S, Kay AB, Jeffery PK: T lymphocytes and activated eosinophils in airway mucosa in fatal asthma and cystic fibrosis. Am Rev Respir Dis 1992; 145:1477-1482.

178 Koller DY, Urbanek R, Götz M: Increased degranulation of eosinophil and neutrophil granulocytes in cystic fibrosis. Am J Respir Crit Care Med 1995;152:629-633. 
179 Koller DY, Nilsson M, Enander I, Venge P, 191 Chang JT, Wherry EJ, Goldrath AW: MoEichler I: Serum eosinophil cationic protein, eosinophil protein $\mathrm{X}$ and eosinophil peroxidase in relation to pulmonary function in cystic fibrosis. Clin Exp Allergy 1998;28: 241-248.

180 O’Driscoll BR, Cromwell O, Kay AB: Sputum leukotrienes in obstructive airways diseases. Clin Exp Immunol 1984;55:397-404.

181 Gleich GJ, Flavahan NA, Fujisawa T, Vanhoutte PM: The eosinophil as a mediator of damage to respiratory epithelium: a model for bronchial hyperreactivity. J Allergy Clin Immunol 1988;81:776-781.

182 Halmerbauer G, Arri S, Schierl M, Strauch E, Koller DY: The relationship of eosinophil granule proteins to ions in the sputum of patients with cystic fibrosis. Clin Exp Allergy 2000;30:1771-1776.

183 Farahi N, Uller L, Juss JK, Langton AJ, Cowburn AS, Gibson A, Foster MR, Farrow SN, Marco-Casanova P, Sobolewski A, Condliffe AM, Chilvers ER: Effects of the cyclin-dependent kinase inhibitor R-roscovitine on eosinophil survival and clearance. Clin Exp Allergy 2011;41:673-687.

184 Odemuyiwa SO, Ilarraza R, Davoine F, Logan MR, Shayeganpour A, Wu Y, Majaesic C, Adamko DJ, Moqbel R, Lacy P: Cyclindependent kinase 5 regulates degranulation in human eosinophils. Immunology 2015; 144:641-648.

185 Lilja L, Yang SN, Webb DL, Juntti-Berggren L, Berggren PO, Bark C: Cyclin-dependent kinase 5 promotes insulin exocytosis. J Biol Chem 2001;276:34199-34205.

-186 Lilja L, Johansson JU, Gromada J, Mandic SA, Fried G, Berggren PO, Bark C: Cyclindependent kinase 5 associated with $\mathrm{p} 39$ promotes Munc18-1 phosphorylation and $\mathrm{Ca}^{2+}$-dependent exocytosis. J Biol Chem 2004;279:29534-29541.

-187 Duffin R, Leitch AE, Sheldrake TA, Hallett JM, Meyer C, Fox S, Alessandri AL, Martin MC, Brady HJ, Teixeira MM, Dransfield I, Haslett C, Rossi AG: The CDK inhibitor, Rroscovitine, promotes eosinophil apoptosis by down-regulation of Mcl-1. FEBS Lett 2009;583:2540-2546.

188 Felton JM, Lucas CD, Rossi AG, Dransfield I: Eosinophils in the lung - modulating apoptosis and efferocytosis in airway inflammation. Front Immunol 2014;5:302.

-189 Alessandri AL, Duffin R, Leitch AE, Lucas CD, Sheldrake TA, Dorward DA, Hirani N, Pinho V, de Sousa LP, Teixeira MM, Lyons JF, Haslett C, Rossi AG: Induction of eosinophil apoptosis by the cyclin-dependent kinase inhibitor AT7519 promotes the resolution of eosinophil-dominant allergic inflammation. PLoS One 2011;6:e25683.

190 Lucas CD, Dorward DA, Sharma S, Rennie J, Felton JM, Alessandri AL, Duffin R, Schwarze J, Haslett C, Rossi AG: Wogonin induces eosinophil apoptosis and attenuates allergic airway inflammation. Am J Respir Crit Care Med 2015;191:626-636. lecular regulation of effector and memory $\mathrm{T}$ cell differentiation. Nat Immunol 2014;15: 1104-1115.

192 Zhou L, Chong MM, Littman DR: Plasticity of CD4+ T cell lineage differentiation. Immunity 2009;30:646-655.

193 Kleinewietfeld M, Hafler DA: The plasticity of human Treg and Th17 cells and its role in autoimmunity. Semin Immunol 2013;25: 305-312.

194 Kushwah R, Gagnon S, Sweezey NB: Intrinsic predisposition of naïve cystic fibrosis $\mathrm{T}$ cells to differentiate towards a Th17 phenotype. Respir Res 2013;14:138.

195 Mulcahy EM, Hudson JB, Beggs SA, Reid DW, Roddam LF, Cooley MA: High peripheral blood Th17 percent associated with poor lung function in cystic fibrosis. PLoS One 2015; 10:e0120912.

196 Tiringer K, Treis A, Fucik P, Gona M, Gruber S, Renner S, Dehlink E, Nachbaur E, Horak F, Jaksch P, Döring G, Crameri R, Jung A, Rochat MK, Hörmann M, Spittler A, Klepetko W, Akdis CA, Szépfalusi Z, Frischer T, Eiwegger T: A Th17- and Th2skewed cytokine profile in cystic fibrosis lungs represents a potential risk factor for Pseudomonas aeruginosa infection. Am J Respir Crit Care Med 2013;187:621-629.

197 Tan HL, Regamey N, Brown S, Bush A, Lloyd CM, Davies JC: The Th17 pathway in cystic fibrosis lung disease. Am J Respir Crit Care Med 2011;184:252-258.

198 Decraene A, Willems-Widyastuti A, Kasran A, De Boeck K, Bullens DM, Dupont LJ: Elevated expression of both mRNA and protein levels of IL-17A in sputum of stable cystic fibrosis patients. Respir Res 2010;11:177.

199 Dubin PJ, McAllister F, Kolls JK: Is cystic fibrosis a TH17 disease? Inflamm Res 2007; 56:221-227.

200 Iannitti RG, Carvalho A, Cunha C, De Luca A, Giovannini G, Casagrande A, Zelante T, Vacca C, Fallarino F, Puccetti P, MassiBenedetti C, Defilippi G, Russo M, Porcaro L, Colombo C, Ratclif L, De Benedictis FM, Romani L: Th17/Treg imbalance in murine cystic fibrosis is linked to indoleamine 2,3-dioxygenase deficiency but corrected by kynurenines. Am J Respir Crit Care Med 2013;187:609-620.

201 Kreindler JL, Steele C, Nguyen N, Chan YR, Pilewski JM, Alcorn JF, Vyas YM, Aujla SJ, Finelli P, Blanchard M, Zeigler SF, Logar A, Hartigan E, Kurs-Lasky M, Rockette H, Ray A, Kolls JK: Vitamin $\mathrm{D}_{3}$ attenuates Th2 responses to Aspergillus fumigatus mounted by $\mathrm{CD} 4^{+} \mathrm{T}$ cells from cystic fibrosis patients with allergic bronchopulmonary aspergillosis. J Clin Invest 2010;120:3242-3254.

202 Anil N, Singh M: CD $4^{+} \mathrm{CD} 25^{\text {high }}$ FOXP3 $^{+}$ regulatory $\mathrm{T}$ cells correlate with $\mathrm{FEV}_{1}$ in North Indian children with cystic fibrosis. Immunol Invest 2014;43:535-543.
203 Hector A, Schäfer H, Pöschel S, Fischer A, Fritzsching B, Ralhan A, Carevic M, Öz H, Zundel S, Hogardt M, Bakele M, Rieber N, Riethmueller J, Graepler-Mainka U, Stahl M, Bender A, Frick JS, Mall M, Hartl D: Regulatory T-cell impairment in cystic fibrosis patients with chronic pseudomonas infection. Am J Respir Crit Care Med 2015;191:914-923.

204 Ziai S, Coriati A, Gauthier MS, Rabasa-Lhoret R, Richter MV: Could T cells be involved in lung deterioration and hyperglycemia in cystic fibrosis? Diabetes Res Clin Pract 2014; 105:22-29.

205 Robinson KM, Alcorn JF: T-cell immunotherapy in cystic fibrosis: weighing the risk/ reward. Am J Respir Crit Care Med 2013; 187:564-566.

206 Tan HL, Rosenthal M: IL-17 in lung disease: friend or foe? Thorax 2013;68:788-790.

207 Yoshida H, Kotani H, Kondo T, Tani I, Wei X, Tsuruta S, Kimura A, Asakawa M, Ito M, Nagai S, Yoshimura A: CDK inhibitors suppress Th17 and promote iTreg differentiation, and ameliorate experimental autoimmune encephalomyelitis in mice. Biochem Biophys Res Commun 2013;435:378-384.

208 Zhang Z, Liu Q, Leskov KS, Wu X, Duan J, Zhang GL, Hall M, Rosenbaum JT: Roscovitine suppresses CD4+ T cells and T cell-mediated experimental uveitis. PLoS One 2013; 8:e81154.

209 Li L, Wang H, Kim JS, Pihan G, Boussiotis V: The cyclin dependent kinase inhibitor (R)-roscovitine prevents alloreactive $\mathrm{T}$ cell clonal expansion and protects against acute GvHD. Cell Cycle 2009;8:1794-1802.

$210 \mathrm{Gu}$ H, Ding L, Xiong SD, Gao XM, Zheng B: Inhibition of CDK2 promotes inducible regulatory T-cell differentiation through TGF $\beta$ Smad3 signaling pathway. Cell Immunol 2014;290:138-144.

211 Khor B, Gagnon JD, Goel G, Roche MI, Conway KL, Tran K, Aldrich LN, Sundberg TB, Paterson AM, Mordecai S, Dombkowski D, Schirmer M, Tan PH, Bhan AK, Roychoudhuri R, Restifo NP, O'Shea JJ, Medoff BD, Shamji AF, Schreiber SL, Sharpe AH, Shaw SY, Xavier RJ: The kinase DYRK1A reciprocally regulates the differentiation of Th17 and regulatory $\mathrm{T}$ cells. Elife 2015;4:e05920.

212 Kim ND, Yoon J, Kim JH, Lee JT, Chon YS, Hwang MK, Ha I, Song WJ: Putative therapeutic agents for the learning and memory deficits of people with Down syndrome. Bioorg Med Chem Lett 2006;16:3772-3776.

213 Havermans T, Colpaert K, De Boeck K, Dupont L, Abbott J: Pain in CF: review of the literature. J Cyst Fibros 2013;12:423-430.

214 Nash EF, Ohri CM, Stephenson AL, Durie PR: Abdominal pain in adults with cystic fibrosis. Eur J Gastroenterol Hepatol 2014;26: 129-136.

215 Utreras E, Futatsugi A, Pareek TK, Kulkarni AB: Molecular roles of Cdk5 in pain signaling. Drug Discov Today Ther Strateg 2009; 6:105-111. 
-216 Pareek TK, Keller J, Kesavapany S, Pant HC, Iadarola MJ, Brady RO, Kulkarni AB: Cyclin-dependent kinase 5 activity regulates pain signaling. Proc Natl Acad Sci USA 2006;103:791-796.

-217 Prochazkova M, Terse A, Amin ND, Hall B, Utreras E, Pant HC, Kulkarni AB: Activation of cyclin-dependent kinase 5 mediates orofacial mechanical hyperalgesia. Mol Pain 2013;9:66.

-218 Yang YR, He Y, Zhang Y, Li Y, Li Y, Han Y, Zhu H, Wang Y: Activation of cyclin-dependent kinase $5(\mathrm{Cdk} 5)$ in primary sensory and dorsal horn neurons by peripheral inflammation contributes to heat hyperalgesia. Pain 2007;127:109-120.

-219 Wang CH, Lee TH, Tsai YJ, Liu JK, Chen YJ, Yang LC, Lu CY: Intrathecal cdk5 inhibitor, roscovitine, attenuates morphine antinociceptive tolerance in rats. Acta Pharmacol Sin 2004;25:1027-1030.

220 Fang H, Zhang HH, Yang BX, Huang JL, Shun JL, Kong FJ, Peng X, Chen ZG, Lu JM: Cdk 5 contributes to inflammation-induced thermal hyperalgesia mediated by the p38 MAPK pathway in microglia. Brain Res 2015;1619:166-175.

-221 Zhang HH, Zhang XQ, Wang WY, Xue QS, $\mathrm{Lu} \mathrm{H}$, Huang JL, Gui T, Yu BW: Increased synaptophysin is involved in inflammationinduced heat hyperalgesia mediated by cyclin-dependent kinase 5 in rats. PLoS One 2012; 7:e46666.

-222 Zhang HH, Zhang XQ, Xue QS, Yan L, Huang JL, Zhang S, Shao HJ, Lu H, Wang WY, Yu BW: The BDNF/TrkB signaling pathway is involved in heat hyperalgesia mediated by Cdk5 in rats. PLoS One 2014; 9:e85536.

-223 Zhang X, Zhang H, Shao H, Xue Q, Yu B: ERK MAP kinase activation in spinal cord regulates phosphorylation of Cdk5 at serine 159 and contributes to peripheral inflammation induced pain/hypersensitivity. PLoS One 2014;9:e87788.

-224 Xing BM, Yang YR, Du JX, Chen HJ, Qi C, Huang ZH, Zhang Y, Wang Y: Cyclin-dependent kinase 5 controls TRPV1 membrane trafficking and the heat sensitivity of nociceptors through KIF13B. J Neurosci 2012;32:14709-14721.

225 Liu J, Du J, Yang Y, Wang Y: Phosphorylation of TRPV1 by cyclin-dependent kinase 5 promotes TRPV1 surface localization, leading to inflammatory thermal hyperalgesia. Exp Neurol 201;273:253-262.

226 Pareek TK, Keller J, Kesavapany S, Agarwal N, Kuner R, Pant HC, Iadarola MJ, Brady RO, Kulkarni AB: Cyclin-dependent kinase
5 modulates nociceptive signaling through direct phosphorylation of transient receptor potential vanilloid 1. Proc Natl Acad Sci USA 2007;104:660-665.

227 Li L, Zhang C, Zi X, Tu Q, Guo K: Epigenetic modulation of Cdk5 contributes to memory deficiency induced by amyloid fibrils. Exp Brain Res 2015;233:165-173.

228 Yang L, Gu X, Zhang W, Zhang J, Ma Z: $\mathrm{Cdk} 5$ inhibitor roscovitine alleviates neuropathic pain in the dorsal root ganglia by downregulating N-methyl-D-aspartate receptor subunit 2A. Neurol Sci 2014;35: 1365-1371.

229 Liu X, Liu Y, Zhang J, Zhang W, Sun YE, $\mathrm{Gu} \mathrm{X}, \mathrm{Ma} Z$ : Intrathecal administration of roscovitine prevents remifentanil-induced postoperative hyperalgesia and decreases the phosphorylation of N-methyl-D-aspartate receptor and metabotropic glutamate receptor 5 in spinal cord. Brain Res Bull 2014;106:9-16.

230 Zhang R, Liu Y, Zhang J, Zheng Y, Gu X, Ma $Z$ : Intrathecal administration of roscovitine attenuates cancer pain and inhibits the expression of NMDA receptor $2 \mathrm{~B}$ subunit mRNA. Pharmacol Biochem Behav 2012; 102:139-145.

231 Wang CH, Chou WY, Hung KS, Jawan B, Lu CN, Liu JK, Hung YP, Lee TH: Intrathecal administration of roscovitine inhibits Cdk5 activity and attenuates formalin-induced nociceptive response in rats. Acta Pharmacol Sin 2005;26:46-50.

232 Peng HY, Chen GD, Tung KC, Lai CY, Hsien MC, Chiu CH, Lu HT, Liao JM, Lee SD, Lin TB: Colon mustard oil instillation induced cross-organ reflex sensitization on the pelvic-urethra reflex activity in rats. Pain 2009;142:75-88.

233 Evaluation of (R)-roscovitine safety and effects in subjects with cystic fibrosis, homozygous for the F508del-CFTR mutation (ROSCO-CF). https://clinicaltrials.gov/ ct2/show/NCT02649751?term=roscovitine\& rank $=1$.

234 Dekkers JF, Wiegerinck CL, de Jonge HR, Bronsveld I, Janssens HM, de Winter-de Groot KM, Brandsma AM, de Jong NW, Bijvelds MJ, Scholte BJ, Nieuwenhuis EE, van den Brink S, Clevers $\mathrm{H}$, van der Ent CK, Middendorp S, Beekman JM: A functional CFTR assay using primary cystic fibrosis intestinal organoids. Nat Med 2013;19:939945.

235 Sun X, Olivier AK, Liang B, Yi Y, Sui H, Evans TI, Zhang Y, Zhou W, Tyler SR, Fisher JT, Keiser NW, Liu X, Yan Z, Song Y, Goeken JA, Kinyon JM, Fligg D, Wang X, Xie W,
Lynch TJ, Kaminsky PM, Stewart ZA, Pope RM, Frana T, Meyerholz DK, Parekh K, Engelhardt JF: Lung phenotype of juvenile and adult cystic fibrosis transmembrane conductance regulator-knockout ferrets. Am J Respir Cell Mol Biol 2014;50:502-512.

236 Sun X, Sui H, Fisher JT, Yan Z, Liu X, Cho HJ, Joo NS, Zhang Y, Zhou W, Yi Y, Kinyon JM, Lei-Butters DC, Griffin MA, Naumann P, Luo M, Ascher J, Wang K, Frana T, Wine JJ, Meyerholz DK, Engelhardt JF: Disease phenotype of a ferret CFTR-knockout model of cystic fibrosis. J Clin Invest 2010;120: 3149-3160.

237 Yan Z, Stewart ZA, Sinn PL, Olsen JC, Hu J, McCray PB Jr, Engelhardt JF: Ferret and pig models of cystic fibrosis: prospects and promise for gene therapy. Hum Gene Ther Clin Dev 2015;26:38-49.

238 Harrison F, Muruli A, Higgins S, Diggle SP: Development of an ex vivo porcine lung model for studying growth, virulence, and signaling of Pseudomonas aeruginosa. Infect Immun 2014;82:3312-3323.

239 Kukavica-Ibrulj I, Facchini M, Cigana C, Levesque RC, Bragonzi A: Assessing Pseudomonas aeruginosa virulence and the host response using murine models of acute and chronic lung infection. Methods Mol Biol 2014;1149:757-771.

240 Green H, Jones AM: The microbiome and emerging pathogens in cystic fibrosis and non-cystic fibrosis bronchiectasis. Semin Respir Crit Care Med 2015;36:225-235.

241 Parkins MD, Floto RA: Emerging bacterial pathogens and changing concepts of bacterial pathogenesis in cystic fibrosis. J Cyst Fibros 2015;14:293-304.

242 Hill UG, Floto RA, Haworth CS: Non-tuberculous mycobacteria in cystic fibrosis. JR Soc Med 2012;105:S14-S18.

243 Wainwright CE, Elborn JS, Ramsey BW, Marigowda G, Huang X, Cipolli M, Colombo C, Davies JC, De Boeck K, Flume PA, Konstan MW, McColley SA, McCoy K, McKone EF, Munck A, Ratjen F, Rowe SM, Waltz D, Boyle MP; TRAFFIC Study Group; TRANSPORT Study Group: Lumacaftorivacaftor in patients with cystic fibrosis homozygous for Phe508del CFTR. N Engl J Med 2015;373:220-231.

244 Legraverend M, Grierson DS: The purines: potent and versatile small molecule inhibitors and modulators of key biological targets. Bioorg Med Chem 2006;14:3987-4006.

245 Sharma S, Mehndiratta S, Yadav S, Singh M, Bedi PM, Nepali K: Purine analogues as kinase inhibitors: a review. Recent Pat Anticancer Drug Discov 2015;10:308-341. 